Article

\title{
Structure and Catalytic Behavior of Alumina Supported Bimetallic Au-Rh Nanoparticles in the Reduction of $\mathrm{NO}$ by $\mathrm{CO}$
}

\author{
Xianwei Wang ${ }^{1}$, Hongji Wang ${ }^{1}$, Nobutaka Maeda ${ }^{1, *}$ and Alfons Baiker ${ }^{2, *} \mathbb{C}$ \\ 1 Key Laboratory of Industrial Ecology and Environmental Engineering, School of Environmental Science and \\ Technology, Dalian University of Technology, Dalian 116024, China; xianwei.wang@unige.ch (X.W.); \\ wanghongji419@163.com (H.W.) \\ 2 Department of Chemistry and Applied Biosciences, Institute for Chemical and Bioengineering, ETH Zurich, \\ Hönggerberg, HCI, CH-8093 Zurich, Switzerland \\ * Correspondence: nobutaka.maeda@dlut.edu.cn (N.M.); alfons.baiker@chem.ethz.ch (A.B.); \\ Tel.: +81-090-6742-4738 (N.M.); +41-44-632-3153 (A.B.)
}

Received: 30 September 2019; Accepted: 6 November 2019; Published: 8 November 2019

\begin{abstract}
Alumina-supported bimetallic AuRh catalysts, as well as monometallic reference catalysts, were examined with regard to their structural and catalytic properties in the reduction of $\mathrm{NO}$ by $\mathrm{CO}$. Depending on the molar ratio of $\mathrm{Au}: \mathrm{Rh}$, the nanoparticles prepared by borohydride co-reduction of corresponding metal salt solutions had a size of $3.5-6.7 \mathrm{~nm}$. The particles consisted of well-dispersed noble metal atoms with some enrichment of $\mathrm{Rh}$ in their surface region. NO conversion of $\mathrm{AuRh} / \mathrm{Al}_{2} \mathrm{O}_{3}$ shifted to lower temperatures with increasing $\mathrm{Rh}$ content, reaching highest activity and highest $\mathrm{N}_{2}$ selectivity for the monometallic $\mathrm{Rh} / \mathrm{Al}_{2} \mathrm{O}_{3}$ catalyst. This behavior is attributed to the enhanced adsorption of $\mathrm{CO}$ on the bimetallic catalyst resulting in unfavorable cationic $\mathrm{Rh}$ clusters $\mathrm{Rh}^{+}-(\mathrm{CO})_{2}$. Doping with ceria of $\mathrm{AuRh} / \mathrm{Al}_{2} \mathrm{O}_{3}$ and $\mathrm{Rh} / \mathrm{Al}_{2} \mathrm{O}_{3}$ catalysts increased the surface population of metallic $\mathrm{Rh}$ sites, which are considered most active for the reduction of $\mathrm{NO}$ by $\mathrm{CO}$ and enhancement of the formation of intermediate isocyanate (-NCO) surface species and their reaction with $\mathrm{NO}$ to form $\mathrm{N}_{2}$ and $\mathrm{CO}_{2}$.
\end{abstract}

Keywords: alumina-supported AuRh nanoparticles; ceria doping; in situ DRIFTS; nitric oxide reduction with carbon monoxide; reaction mechanism

\section{Introduction}

Anthropogenic emissions of nitrogen oxides from fuel combustion processes pose a serious threat to human health. Since the reaction of $\mathrm{CO}$ and $\mathrm{NO}$ can eliminate two harmful pollution gases simultaneously, it has attracted a great deal of attention especially in automobile exhaust applications in a wide range of temperature and pressure [1,2]. Typically, noble metals such as $\mathrm{Rh}, \mathrm{Pt}$, and $\mathrm{Pd}$ are employed for the NO reduction and $\mathrm{CO}$ oxidation [3-9]. Among the studies reported so far, the NO reduction by $\mathrm{CO}$ and co-adsorption on $\mathrm{Pd}$ surfaces, as well as co-adsorption of $\mathrm{NO}$ and $\mathrm{CO}$ on platinum catalysts, have been extensively studied [6-9]. The formation and migration of isocyanate species are considered to be crucial for efficient catalytic cycles [8].

Due to its low reactivity, gold has long been disregarded as a candidate for heterogeneous catalysis until its nanoparticles supported on oxidic materials were discovered to catalyze the oxidation of $\mathrm{CO}$ even below room temperature [10]. The choice of metal oxide supports strongly affects the structural and chemical properties of $\mathrm{Au}$-metal oxide interfaces and is therefore a crucial factor in the design of such catalysts [11-16]. The unique properties of gold, such as chemical stability, non-toxicity, and biocompatibility [11], make gold catalysts attractive for various reactions, including oxidations and 
hydrogenations [17-20]. Gold and its alloys with other metals show interesting performance in the $\mathrm{NO}$ reduction by $\mathrm{CO}$, and thus, structurally optimized Au catalysts provide an attractive research direction [16]. Different Au-based catalysts synthesized by coprecipitation or deposition-precipitation methods have been tested for this reaction [15,21-24], among which Au supported on Fe-loaded ceria shows high NO conversion and stability [21]. Au-Pd alloy catalysts exhibit high selectivity, compared to pure Pd catalysts [25], showing further potential of bimetallic gold-based catalysts.

Generally, the reaction steps of NO reduction by CO can be expressed as follows $[7,26]$ :

$$
\begin{gathered}
2 \mathrm{CO}+2 \mathrm{NO} \rightarrow \mathrm{N}_{2}+2 \mathrm{CO}_{2}, \\
\mathrm{CO}+2 \mathrm{NO} \rightarrow \mathrm{N}_{2} \mathrm{O}+\mathrm{CO}_{2}, \\
\mathrm{CO}+\mathrm{N}_{2} \mathrm{O} \rightarrow \mathrm{N}_{2}+\mathrm{CO}_{2} .
\end{gathered}
$$

Reaction (1) directly forms $\mathrm{N}_{2}$ while an alternative path requires reactions (2) and (3), where $\mathrm{N}_{2} \mathrm{O}$ is formed as an intermediate. Depending on the metal oxide support, $\mathrm{Au}$ nanoparticles offer high $\mathrm{N}_{2}$ selectivity, whereas the main product is $\mathrm{N}_{2} \mathrm{O}$ over unsupported Au catalysts [22,25]. Therefore, the presence of pertinent $\mathrm{Au}$-metal oxide interfaces promotes reactions (1) and (3). In situ IR spectroscopic studies revealed that $\mathrm{CO}$ and $\mathrm{NO}$ adsorb in various configurations, i.e., on-top $\mathrm{Au}^{\delta+}-\mathrm{CO}$, $\mathrm{CO}$ on $\mathrm{Au}^{0}$ particles $\left(\mathrm{Au}_{s}{ }^{0}-\mathrm{CO}\right)$, bridged $\mathrm{NO}(\mathrm{Au}-\mathrm{NO})$, and on-top $\mathrm{NO}^{-}$species $\left(\mathrm{Au}-\mathrm{NO}^{-}\right)$[23,27-29]. Their reaction on the Au surface forms isocyanate (-NCO) species, which are considered to be a key reaction intermediate that migrates to the oxide support [30,31].

In recent research on $\mathrm{NO}_{\mathrm{x}}$ reduction, ceria as a support material or as a promoter of the active metals has been the focus for activity enhancement [32,33]. Different dispersions and sizes of $\mathrm{CeO}_{2}$ nanoparticles influence the catalytic performance [34]. The use of ceria was reported to induce strong metal-support interaction (SMSI) with active metal components. The dispersion of the metal was thus improved by the SMSI effect $[32,35,36]$. Besides, the oxygen vacancies, present at the interface between the ceria and the metal, impart high oxygen storage capacity to the catalyst and facilitate the transport of oxygen from the ceria to the metal surface, resulting in high activity for $\mathrm{NO}_{\mathbf{x}}$ reduction [37-39].

Bimetallic gold-based alloys can offer interesting synergistic effects in catalysis [40]. While the reduction of $\mathrm{NO}$ by $\mathrm{CO}$ on bimetallic gold-based alloy catalysts containing Pt and Pd has been the focus of various studies [41-44], there exist only a few reports in the literature where the behavior of bimetallic AuRh catalysts has been investigated [45-49]. This may be attributed to the large miscibility gap of the AuRh system [50]. However, it has been shown that borohydride co-reduction of metal salt solutions yields nanoparticles in the bulk-immiscible AuRh system $[47,51]$. To the best of our knowledge, there exists no report where supported bimetallic AuRh catalysts have been examined for the reduction of $\mathrm{NO}$ by $\mathrm{CO}$. Its alloying with Au could result in a favorable catalytic synergy effect, as it has been observed in other reactions [49,51]. With this in mind, we have investigated the structural and chemical properties of pure and ceria-promoted alumina-supported bimetallic AuRh alloy nanoparticles and examined their potential for the catalytic reduction of $\mathrm{NO}$ by $\mathrm{CO}$.

\section{Results and Discussion}

\subsection{Bimetallic $\mathrm{AuRh} / \mathrm{Al}_{2} \mathrm{O}_{3}$ Catalysts}

\subsubsection{Catalyst Characterization}

XRD patterns of the catalysts are shown in Figure 1. The diffraction patterns at $38.1^{\circ}, 44.3^{\circ}, 64.6^{\circ}$, and $77.6^{\circ}$, assigned to $\mathrm{Au}(111), \mathrm{Au}(200), \mathrm{Au}(220)$, and $\mathrm{Au}(311)$, respectively, were clearly observed for $\mathrm{Au} / \mathrm{Al}_{2} \mathrm{O}_{3}$ and $\mathrm{AuRh}(3: 1) / \mathrm{Al}_{2} \mathrm{O}_{3}$ catalysts (molar ratios of $\mathrm{Au}: \mathrm{Rh}$ in the catalysts are given in parentheses) [52]. Further addition of Rh caused a considerable broadening of the $\mathrm{Au}(111)$ reflection and a slight shift toward the $\mathrm{Rh}(111)$ reflection $\left(2 \theta=41.0^{\circ}\right)[53,54]$. There were no distinct diffraction 
peaks of $\mathrm{Au}$ and $\mathrm{Rh}$ observed for $\mathrm{AuRh}(1: 1) / \mathrm{Al}_{2} \mathrm{O}_{3}$ and $\mathrm{AuRh}(1: 3) / \mathrm{Al}_{2} \mathrm{O}_{3}$ catalysts, implying that these catalysts consisted predominantly of well-dispersed bimetallic AuRh nanoparticles on $\mathrm{Al}_{2} \mathrm{O}_{3}$ [54].

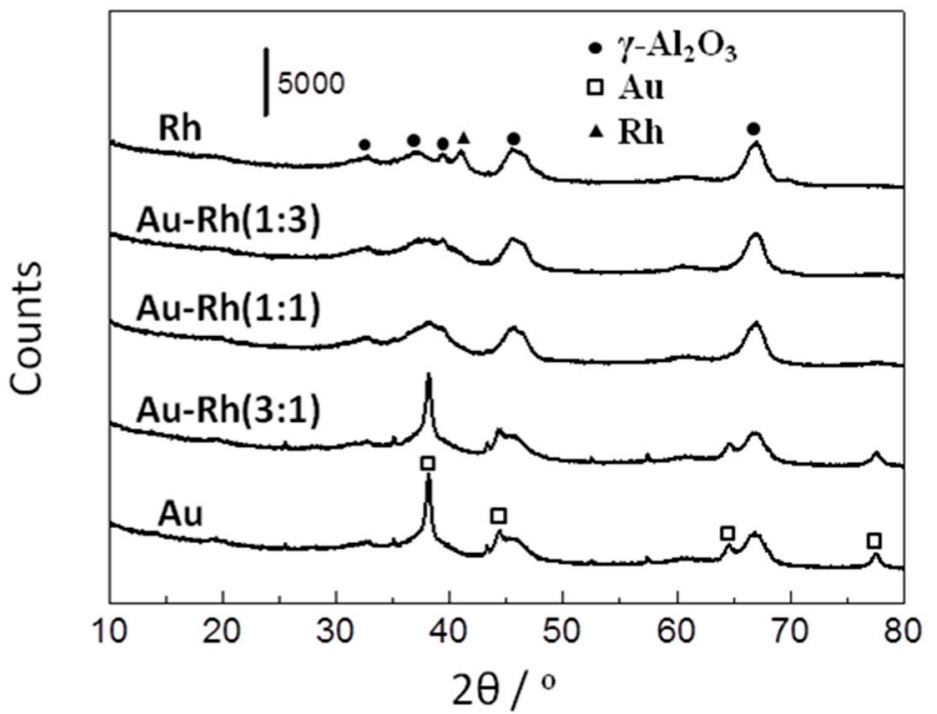

Figure 1. $\mathrm{XRD}$ patterns of $\mathrm{Au} / \mathrm{Al}_{2} \mathrm{O}_{3}, \mathrm{Rh} / \mathrm{Al}_{2} \mathrm{O}_{3}$, and $\mathrm{AuRh} / \mathrm{Al}_{2} \mathrm{O}_{3}$ catalysts with specified molar ratios of Au:Rh.

Figure 2 shows STEM images and metal particle size distributions of various catalysts. Monometallic $\mathrm{Au}$ particles in the $\mathrm{Au} / \mathrm{Al}_{2} \mathrm{O}_{3}$ catalyst were relatively large, whereas their alloying with $\mathrm{Rh}$ resulted in well-dispersed small nanoparticles on the $\mathrm{Al}_{2} \mathrm{O}_{3}$ surface. EDX line scans of selected bimetallic particles, displayed in Figure 3, showed that $\mathrm{Au}$ and $\mathrm{Rh}$ atoms were almost uniformly present in the bimetallic nanoparticles. The apparent absence of bimetallic particles with a distinct core/shell structure, e.g., that often observed for bimetallic PdAu particles [55], might be attributed to the high inter-diffusion rate of $\mathrm{Rh}$ and $\mathrm{Au}$ atoms in the bimetallic particles $[56,57]$ and the fact that the catalysts were pretreated in $\mathrm{H}_{2}$ at $300{ }^{\circ} \mathrm{C}$ before characterization [55].

Table 1 summarizes the results of XPS analyses of the catalysts pretreated with pure $\mathrm{H}_{2}(100 \mathrm{~mL} / \mathrm{min})$ at $300{ }^{\circ} \mathrm{C}$ for $1 \mathrm{~h}$. The raw XPS spectra without background subtraction are shown in Figure S1 (Supplementary Materials). The Au $4 \mathrm{f}_{7 / 2}$ photoelectron peak at a binding energy (BE) between 83.7 and $83.9 \mathrm{eV}$ is attributed to the metallic $\mathrm{Au}^{0}$ species. The reason for the slight shifts of the $\mathrm{Au} 4 \mathrm{f}_{7 / 2}$ $(84 \mathrm{eV})$ and $\mathrm{Rh} 3 \mathrm{~d}_{5 / 2}$ (307.6) signals is probably due to cluster size effects [58] or charging of the samples that mainly consisted of nonconductive $\mathrm{Al}_{2} \mathrm{O}_{3}$. As shown in Table 1, the atomic ratios of $\mathrm{Au} /(\mathrm{Au}+\mathrm{Rh})$ were lower than those expected from the nominal bulk composition of the catalysts, indicating the presence of a segregated Rh-enriched phase in the near-surface region probably due to pretreatment with hydrogen.

Table 1. BET, STEM and X-ray photoelectron spectroscopy (XPS) analyses of $\mathrm{Au} / \mathrm{Al}_{2} \mathrm{O}_{3}, \mathrm{Rh} / \mathrm{Al}_{2} \mathrm{O}_{3}$, and $\mathrm{AuRh} / \mathrm{Al}_{2} \mathrm{O}_{3}$ catalysts with specified molar ratios of $\mathrm{Au}: \mathrm{Rh}$.

\begin{tabular}{|c|c|c|c|c|c|}
\hline \multirow[b]{2}{*}{ Catalyst } & \multirow[b]{2}{*}{$\begin{array}{l}\text { BET surface } \\
\text { area }\left(\mathrm{m}^{2} / \mathrm{g}\right)\end{array}$} & \multirow[b]{2}{*}{$\begin{array}{l}\text { Mean Size of metal } \\
\text { Particles (nm) }\end{array}$} & \multicolumn{3}{|c|}{ XPS } \\
\hline & & & $\begin{array}{c}\text { Binding energy of } \\
\text { Au4f }_{7 / 2}(\mathrm{eV})\end{array}$ & $\begin{array}{l}\text { Binding energy of } \\
\operatorname{Rh}_{3 d_{5 / 2}}(\mathrm{eV})\end{array}$ & $\begin{array}{c}\mathrm{Au} \\
\mathrm{Au}+\mathrm{Rh}\end{array}$ \\
\hline $\mathrm{Rh} / \mathrm{Al}_{2} \mathrm{O}_{3}$ & 160 & 3.5 & - & 307.3 & 0 \\
\hline $\mathrm{Au}-\mathrm{Rh}(1: 3) / \mathrm{Al}_{2} \mathrm{O}_{3}$ & 154 & 3.2 & 83.7 & 307.1 & 0.24 \\
\hline $\mathrm{Au}-\mathrm{Rh}(1: 1) / \mathrm{Al}_{2} \mathrm{O}_{3}$ & 163 & 2.9 & 83.7 & 307.0 & 0.43 \\
\hline $\mathrm{Au}-\mathrm{Rh}(3: 1) / \mathrm{Al}_{2} \mathrm{O}_{3}$ & 161 & 6.7 & 83.9 & 306.9 & 0.63 \\
\hline $\mathrm{Au} / \mathrm{Al}_{2} \mathrm{O}_{3}$ & 171 & 18.1 & 83.9 & - & 1.00 \\
\hline
\end{tabular}



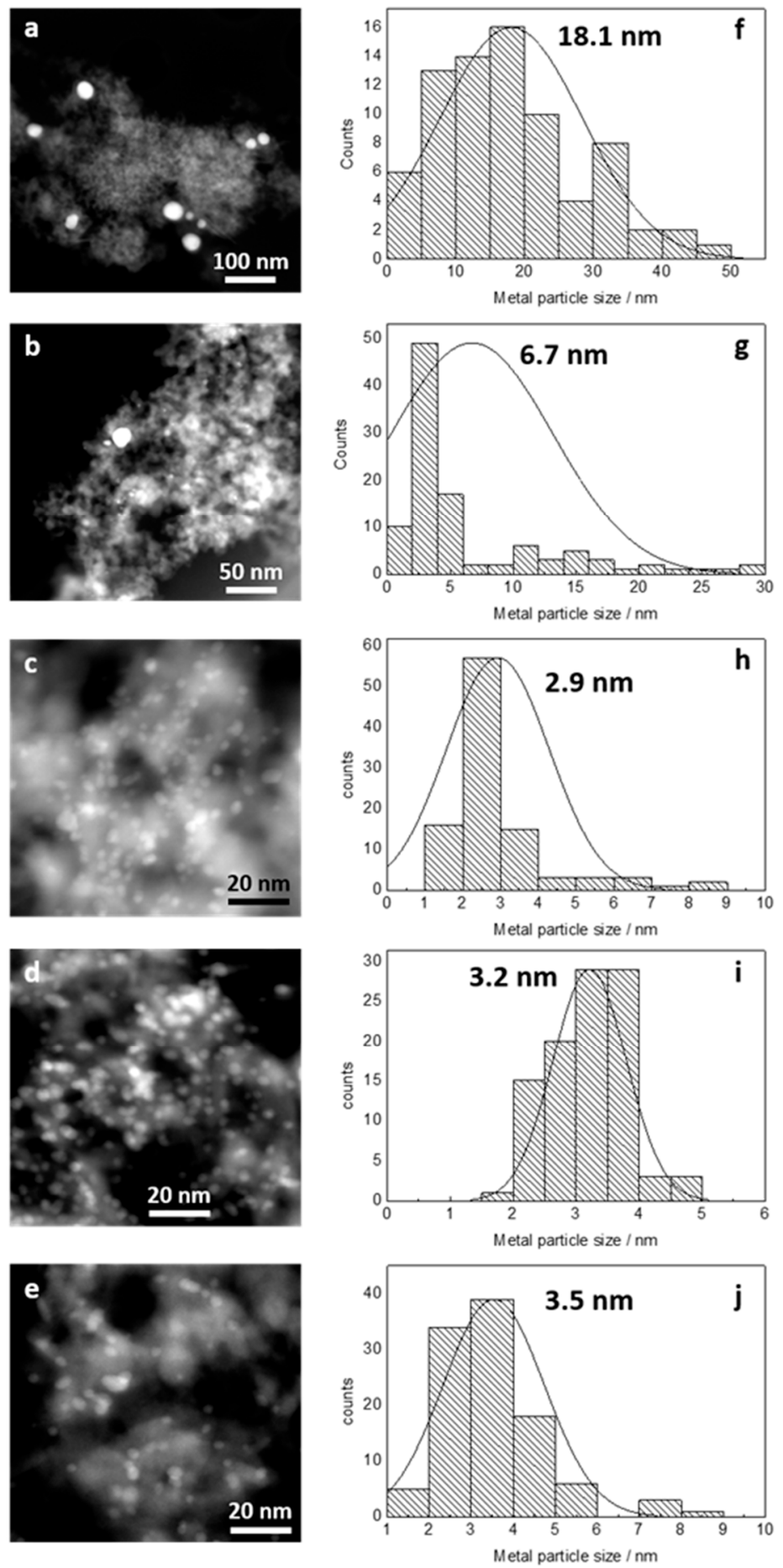

Figure 2. Scanning transmission electron microscopy (STEM) images of different catalysts: (a) $\mathrm{Au} / \mathrm{Al}_{2} \mathrm{O}_{3}$, (b) $\mathrm{AuRh}(3: 1) / \mathrm{Al}_{2} \mathrm{O}_{3}$, (c) $\mathrm{AuRh}(1: 1) / \mathrm{Al}_{2} \mathrm{O}_{3}$, (d) $\mathrm{AuRh}(1: 3) / \mathrm{Al}_{2} \mathrm{O}_{3}$, and (e) $\mathrm{Rh} / \mathrm{Al}_{2} \mathrm{O}_{3}$ catalysts. Particle size distributions of different catalysts: (f) $\mathrm{Au} / \mathrm{Al}_{2} \mathrm{O}_{3}$, (g) $\mathrm{AuRh}(3: 1) / \mathrm{Al}_{2} \mathrm{O}_{3}$, (h) $\mathrm{AuRh}(1: 1) / \mathrm{Al}_{2} \mathrm{O}_{3}$, (i) $\mathrm{AuRh}(1: 3) / \mathrm{Al}_{2} \mathrm{O}_{3}$, and $(\mathbf{j}) \mathrm{Rh} / \mathrm{Al}_{2} \mathrm{O}_{3}$ catalysts. The average particle sizes of the catalysts are indicated in the histograms. 

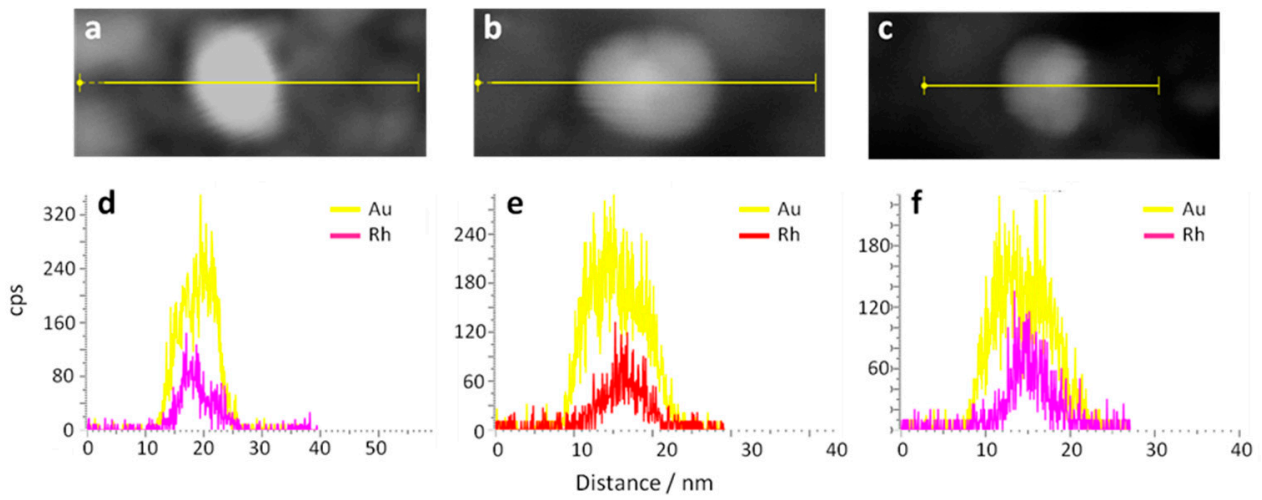

Figure 3. STEM images of selected bimetallic particles: (a) AuRh(3:1)/ $\mathrm{Al}_{2} \mathrm{O}_{3}$, (b) AuRh(1:1)/ $\mathrm{Al}_{2} \mathrm{O}_{3}$, and (c) AuRh(1:3)/ $/ \mathrm{Al}_{2} \mathrm{O}_{3}$. Energy-dispersive X-ray spectroscopy (EDX) line scans of selected bimetallic particles: (d) $\mathrm{AuRh}(3: 1) / \mathrm{Al}_{2} \mathrm{O}_{3}$, (e) $\mathrm{AuRh}(1: 1) / \mathrm{Al}_{2} \mathrm{O}_{3}$, and (f) $\mathrm{AuRh}(1: 3) / \mathrm{Al}_{2} \mathrm{O}_{3}$.

\subsubsection{Catalytic Performance}

The behavior (NO conversion and $\mathrm{N}_{2}$ selectivity) of the $\mathrm{AuRh} / \mathrm{Al}_{2} \mathrm{O}_{3}$ catalysts with different compositions is shown in Figure 4. The $\mathrm{Au} / \mathrm{Al}_{2} \mathrm{O}_{3}$ catalyst showed poor performance and no $\mathrm{N}_{2}$ selectivity even at $250{ }^{\circ} \mathrm{C}$. This is partly attributed to the relatively large size of the deposited gold particles and poor activity for the reduction of the formed $\mathrm{N}_{2} \mathrm{O}$ by $\mathrm{CO}$ (reaction (3)). The higher the Rh content was, the better the activity was, while the $\mathrm{N}_{2}$ selectivity was zero for temperatures up to $200{ }^{\circ} \mathrm{C}$ with all bimetallic catalysts (see also Table S1 in Supplementary Materials). The increase in the $\mathrm{N}_{2}$ selectivity by the $\mathrm{Rh}$ addition is attributed to an increase of the rate of reaction (3). The only by-product was $\mathrm{N}_{2} \mathrm{O}$, while $\mathrm{NO}_{2}$ was not detected. Note that $\mathrm{Rh} / \mathrm{Al}_{2} \mathrm{O}_{3}$ outperformed all bimetallic AuRh catalysts. To gain some insight into the role of both metals, Au and Rh, in the NO reduction by $\mathrm{CO}$, we used the in situ DRIFT spectroscopy.
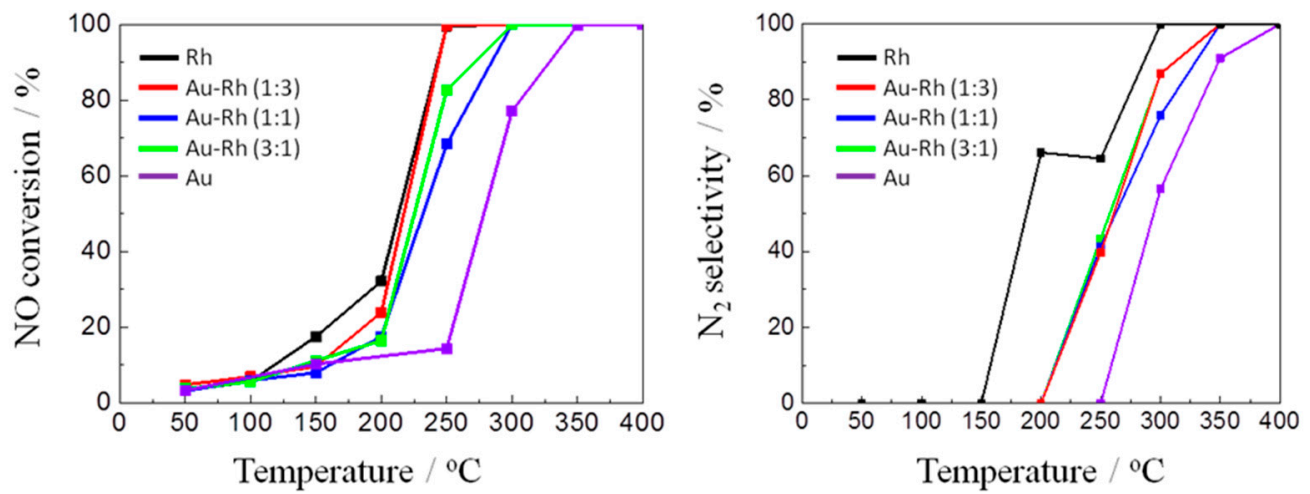

Figure 4. $\mathrm{NO}$ conversion and $\mathrm{N}_{2}$ selectivity of $\mathrm{Au} / \mathrm{Al}_{2} \mathrm{O}_{3}, \mathrm{Rh} / \mathrm{Al}_{2} \mathrm{O}_{3}$, and $\mathrm{AuRh} / \mathrm{Al}_{2} \mathrm{O}_{3}$ catalysts with different molar ratios of Au:Rh. Conditions: gas mixture, 2000 ppm NO, 2000 ppm CO, and He balance; total flow rate, $150 \mathrm{~mL} / \mathrm{min}$; gas hourly space velocity (GHSV), 18,000 $\mathrm{h}^{-1}$; reaction temperature: $50-400{ }^{\circ} \mathrm{C}$.

\subsubsection{In Situ DRIFTS Study}

In situ DRIFTS spectra taken during the adsorption of $2000 \mathrm{ppm} \mathrm{CO}$ in He balance at $30^{\circ} \mathrm{C}$ for $5 \mathrm{~min}$ (from the red line to the blue line at an interval of $1 \mathrm{~min}$ ) are shown in Figure 5. The adsorption temperature was set to $30^{\circ} \mathrm{C}$ to suppress disturbing desorption and disproportionation of $\mathrm{CO}$ and NO. At the initial stage of CO adsorption, a sharp band at $2069 \mathrm{~cm}^{-1}$ assignable to on-top CO on metallic $\mathrm{Rh}\left(\mathrm{Rh}^{0}-\mathrm{CO}\right)$ emerged [59], followed by a gradual increase in bridged $\mathrm{CO}\left(1910 \mathrm{~cm}^{-1}\right)[60,61]$ together with twin bands at $2091 \mathrm{~cm}^{-1}$ and $2025 \mathrm{~cm}^{-1}$, which were assigned to asymmetric and 
symmetric stretching vibrations of gem-dicarbonyls on $\mathrm{Rh}$ cations, $\mathrm{Rh}^{+}-(\mathrm{CO})_{2}$ [60]. As evident from the XPS data, the Rh particles existed as metallic $\mathrm{Rh}$ after $\mathrm{H}_{2}$ pretreatment. However, $\mathrm{CO}$ adsorption caused the decomposition of the $\mathrm{Rh}$ particles by dispersing cationic $\mathrm{Rh}$ atoms as $\mathrm{Rh}^{+}-(\mathrm{CO})_{2}[62,63]$. Interestingly, by adding $\mathrm{Au}$, the intensity of these bands increased and reached a maximum for the $\mathrm{AuRh}(1: 1) / \mathrm{Al}_{2} \mathrm{O}_{3}$ catalyst. A similar tendency was also observed for on-top $\mathrm{CO}$, indicating that the presence of $\mathrm{Au}$ promoted the $\mathrm{CO}$ adsorption on the $\mathrm{Rh}$ sites. Further addition of $\mathrm{Au}$, as realized in the $\mathrm{AuRh}(3: 1) / \mathrm{Al}_{2} \mathrm{O}_{3}$ catalyst, decreased the intensity by a factor of ca. 10, and the $\mathrm{Au} / \mathrm{Al}_{2} \mathrm{O}_{3}$ catalyst showed only weak bands at $2102 \mathrm{~cm}^{-1}$ and $2170 \mathrm{~cm}^{-1}$, which were assigned to $\mathrm{CO}$ adsorbed on $\mathrm{Au}$ and $\mathrm{Al}_{2} \mathrm{O}_{3}$, respectively [64]. Remarkably, the addition of $\mathrm{Au}$ induced the formation of $\mathrm{Rh}^{+}-(\mathrm{CO})_{2}$ species, which are considered to be dispersed in the form of small clusters [60]. This phenomenon is in good agreement with the XRD data (Figure 1), showing that the diffraction peaks were broadened by alloying Rh with Au.

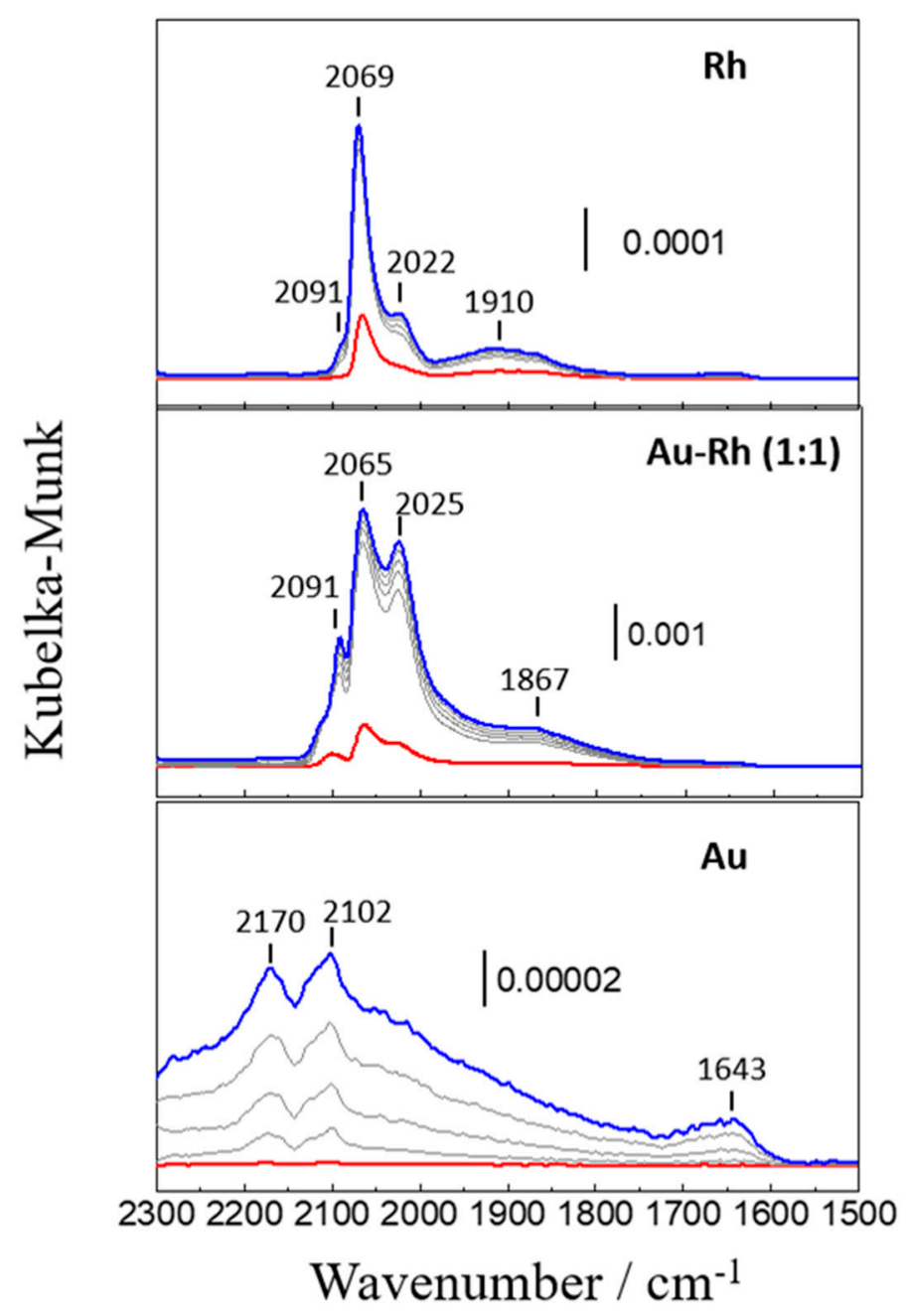

Figure 5. In situ diffuse reflectance IR spectroscopy (DRIFTS) spectra recorded during CO adsorption on the $\mathrm{Rh} / \mathrm{Al}_{2} \mathrm{O}_{3}, \mathrm{AuRh}(1: 1) / \mathrm{Al}_{2} \mathrm{O}_{3}$, and $\mathrm{Au} / \mathrm{Al}_{2} \mathrm{O}_{3}$ catalysts at $30{ }^{\circ} \mathrm{C}$ for $5 \mathrm{~min}$ (from the red line to the blue line at an interval of $1 \mathrm{~min})$. Gas mixture: $2000 \mathrm{ppm} \mathrm{CO}$ and He balance; total flow rate: $100 \mathrm{~mL} / \mathrm{min}$.

DRIFTS spectra measured during NO adsorption (gas mixture: 2000 ppm NO in He balance, total flow rate: $100 \mathrm{~mL} / \mathrm{min}$, temperature: $30^{\circ} \mathrm{C}$, and time duration: $5 \mathrm{~min}$ ) are shown in Figure 6. A sharp band at $1684 \mathrm{~cm}^{-1}$ and a weak band at $1801 \mathrm{~cm}^{-1}$, which can be assigned to on-top $\mathrm{NO}^{\delta-}$ and on-top $\mathrm{NO}$, respectively, were observed for the $\mathrm{Rh} / \mathrm{Al}_{2} \mathrm{O}_{3}$ catalyst [3,65]. Bridged $\mathrm{NO}$ was not observed in our 
study. The presence of gold promoted the adsorption of NO, especially for Rh-NO at ca. $1800 \mathrm{~cm}^{-1}$ but decreased the ratio of $\mathrm{Rh}-\mathrm{NO}^{\delta-}$. This was induced by the low electron density of cationic $\mathrm{Rh}$ $\left(\mathrm{Rh}^{+}\right)$for AuRh alloy nanoparticles as evident from the CO adsorption in Figure 5. Therefore, the formation of cationic Rh suppressed the electron back-donation to NO molecules, which did not allow for the negatively-charged on-top $\mathrm{NO}^{\delta-}$ configuration. For the $\mathrm{Au} / \mathrm{Al}_{2} \mathrm{O}_{3}$ catalyst, a broad band at $1652 \mathrm{~cm}^{-1}$ assigned to asym $\left(\mathrm{NO}_{2}\right)$ of surface $\mathrm{NO}_{2}$ species was observed [23]. The band at $1540 \mathrm{~cm}^{-1}$ is attributed to bridging nitrito $\left(\mathrm{NO}_{2}{ }^{-}\right)$in the chelated state [66]. An additional band at $1894 \mathrm{~cm}^{-1}$ was assigned to $\mathrm{NO}$ adsorbed on $\mathrm{Au}$ [67]. Co-adsorption of $\mathrm{NO}$ and $\mathrm{CO}$ indicated that $\mathrm{NO}$ was adsorbed on Rh more strongly than CO (DRIFTS spectra are provided in Figure S2 in Supplementary Materials). However, the AuRh alloy catalysts tended to enrich CO on the surface. This might be the reason why the conversion decreased for the AuRh alloy catalysts due to high CO coverage suppressing the NO adsorption and dissociation.

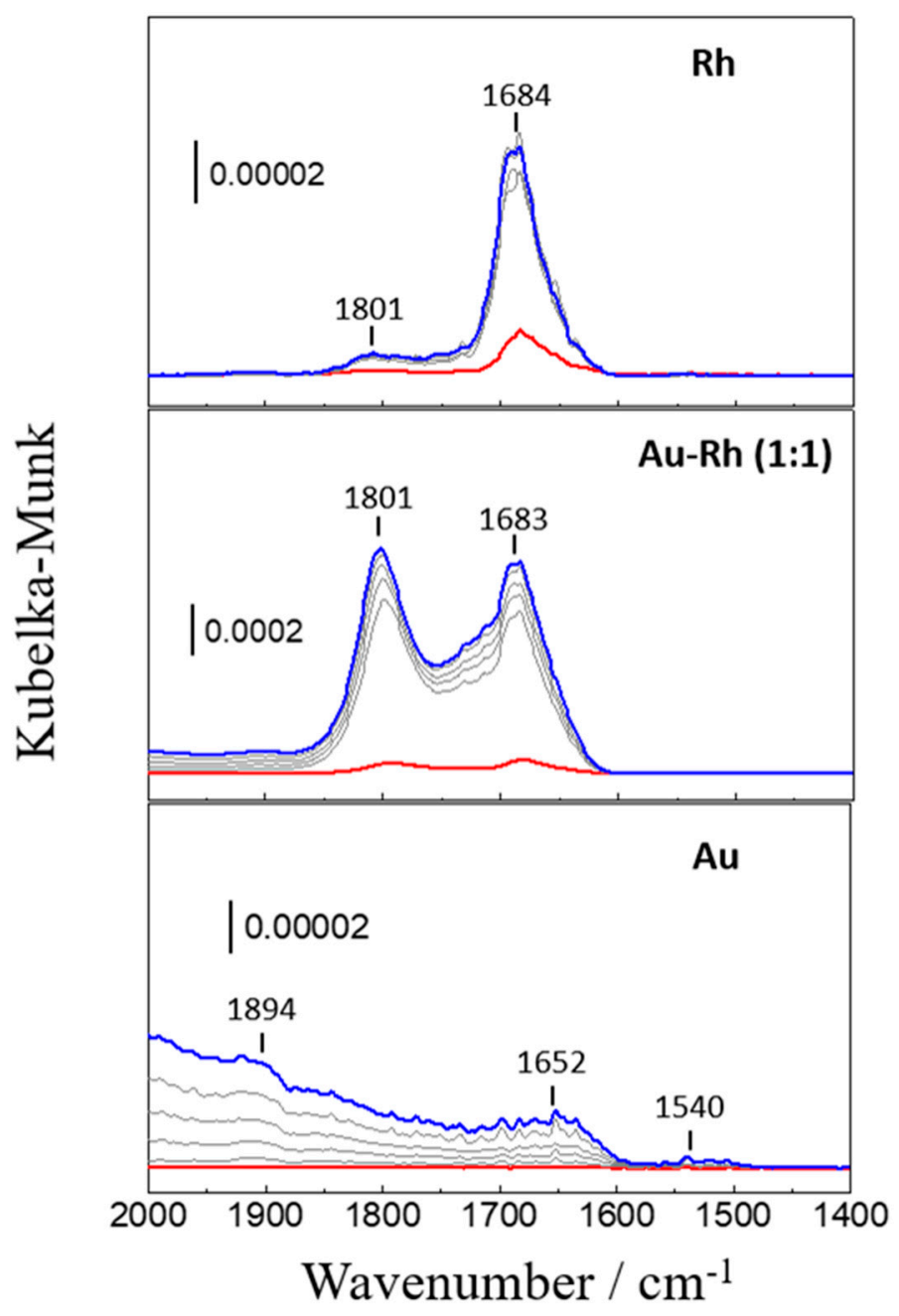

Figure 6. In situ DRIFTS spectra recorded during $\mathrm{NO}$ adsorption on $\mathrm{Rh} / \mathrm{Al}_{2} \mathrm{O}_{3}, \mathrm{AuRh}(1: 1) / \mathrm{Al}_{2} \mathrm{O}_{3}$, and $\mathrm{Au} / \mathrm{Al}_{2} \mathrm{O}_{3}$ catalysts at $30{ }^{\circ} \mathrm{C}$ for $5 \mathrm{~min}$ (from the red line to the blue line at an interval of $1 \mathrm{~min}$ ). Gas mixture: 2000 ppm NO and He balance; total flow rate: $100 \mathrm{~mL} / \mathrm{min}$.

Figure 7 shows DRIFTS spectra during the reduction of $\mathrm{NO}$ by $\mathrm{CO}$ at $300{ }^{\circ} \mathrm{C}$ for $10 \mathrm{~min}$ (from the red line $(5 \mathrm{~s})$ to the blue line $(10 \mathrm{~min})$ at an interval of $1 \mathrm{~min}$; the green line represents a spectrum after 1 min of reaction). At this high temperature, desorption and reaction of $\mathrm{NO}$ and $\mathrm{CO}$ took place rapidly and the corresponding bands were greatly weakened. Instead, several new bands appeared, which are centered at $2254 \mathrm{~cm}^{-1}, 1634 \mathrm{~cm}^{-1}$, and $1404 \mathrm{~cm}^{-1}$, respectively. The catalyst surface was dominated by 
isocyanate species (-NCO) detected at $2254 \mathrm{~cm}^{-1}$. The blue shift compared to previous reports results from the presence of $\mathrm{Rh}^{+}$sites [4]. The shoulder band at ca. $2230 \mathrm{~cm}^{-1}$ was assigned to $\mathrm{Rh}^{0}-\mathrm{NCO}$, which completely disappeared for the $\mathrm{AuRh}(3: 1) / \mathrm{Al}_{2} \mathrm{O}_{3}$ catalyst. Because $\mathrm{N}_{2} \mathrm{O}$ was not detected in the gas phase, the contribution of IR bands of gaseous $\mathrm{N}_{2} \mathrm{O}$ in this region can be excluded. The intensity of isocyanate species first increased, reached a maximum after $4 \mathrm{~min}$ (green line), and then diminished (blue line), accompanied by a weak band at $2049 \mathrm{~cm}^{-1}$ assigned to carbonyl species adsorbed on $\mathrm{Rh}[3,4]$. By adding Au, the intensity of isocyanate species increased and their decomposition also occurred rather rapidly. The decomposition process is better highlighted by switching the gaseous compositions to only 2000 ppm NO in He balance (Figure S3 in Supplementary Materials).

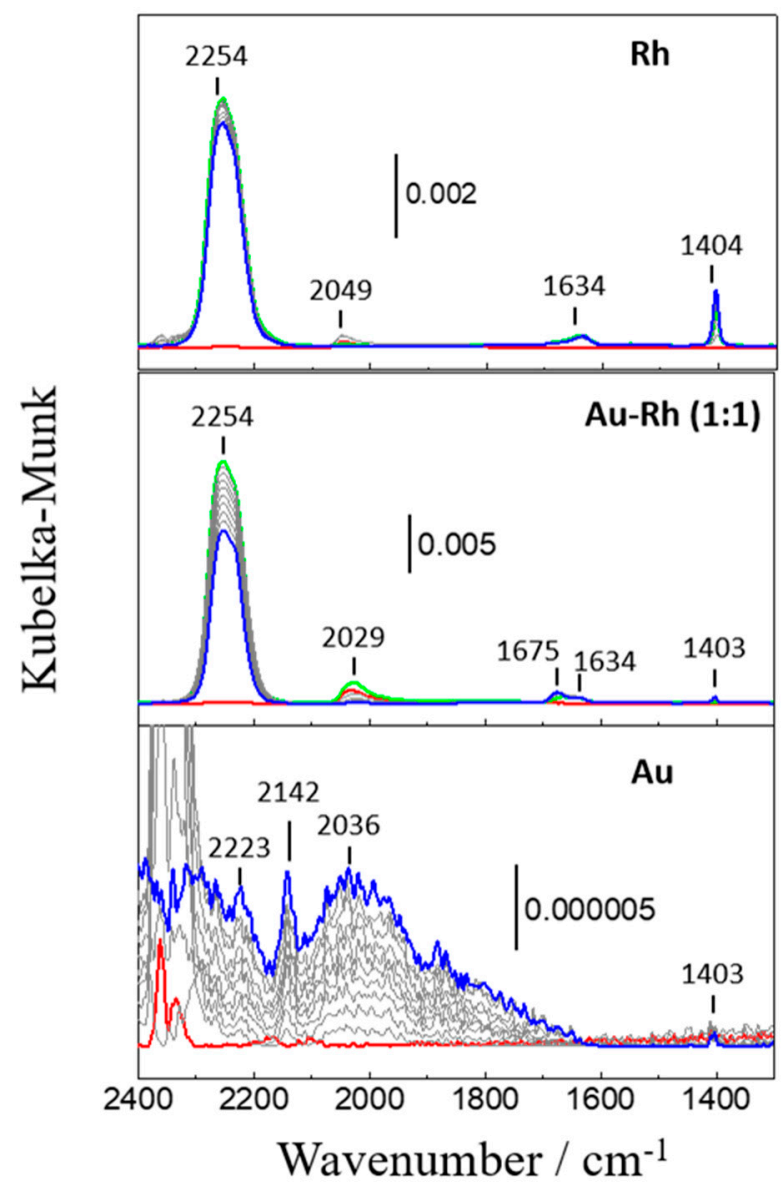

Figure 7. In situ DRIFTS spectra recorded during NO-CO reaction on the $\mathrm{Rh} / \mathrm{Al}_{2} \mathrm{O}_{3}, \mathrm{AuRh}(1: 1) / \mathrm{Al}_{2} \mathrm{O}_{3}$, and $\mathrm{Au} / \mathrm{Al}_{2} \mathrm{O}_{3}$ catalysts at $300{ }^{\circ} \mathrm{C}$ for $10 \mathrm{~min}$ (from the red line to the blue line at an interval of $1 \mathrm{~min}$ ). Gas mixture: 2000 ppm NO, 2000 ppm CO, and He balance; total flow rate: $100 \mathrm{~mL} / \mathrm{min}$.

A plausible reaction pathway is shown as follows:

$$
\begin{aligned}
& \mathrm{Rh}-(\mathrm{NO})(\mathrm{CO})+\mathrm{Rh}^{0} \rightarrow \mathrm{Rh}-\mathrm{N}(\mathrm{CO})+\mathrm{Rh}-\mathrm{O}, \\
& \mathrm{Rh}-\mathrm{N}(\mathrm{CO}) \rightarrow \mathrm{Rh}-\mathrm{NCO}, \\
& \mathrm{Rh}-\mathrm{O}+\mathrm{CO} \rightarrow \mathrm{Rh}^{0}+\mathrm{CO}_{2}, \\
& \mathrm{Rh}-\mathrm{NCO}+\mathrm{NO} \rightarrow \mathrm{Rh}^{0}+\mathrm{CO}_{2}+\mathrm{N}_{2} .
\end{aligned}
$$

A sharp band at $1404 \mathrm{~cm}^{-1}$ was assigned to nitrate species bonding to both $\mathrm{Rh}$ and oxidic support [4], which diminished by adding Au. The negatively charged Rh-(NO) ${ }^{\delta-}$ at $1680 \mathrm{~cm}^{-1}$ and $1634 \mathrm{~cm}^{-1}$ is considered as an active precursor for a key surface reaction step during NO-CO 
reaction $[68,69]$. The lowered wavenumber of $\mathrm{Rh}-\mathrm{NO}^{\delta-}$ indicates a weakening of the $\mathrm{N}-\mathrm{O}$ bond and strengthening of the $\mathrm{Rh}-\mathrm{N}$ bond due to electron back-donation to the $\mathrm{N}-\mathrm{O}$ antibonding orbital $[68,69]$, resulting in higher propensity of NO molecules to be dissociated over reduced Rh surfaces to yield nitride and adsorbed oxygen atoms:

$$
\begin{gathered}
\text { Rh-NO }{ }^{\delta-}+\mathrm{Rh}^{0} \rightarrow \mathrm{Rh}-\mathrm{N}+\mathrm{Rh}-\mathrm{O}, \\
\mathrm{Rh}-\mathrm{N}+\mathrm{Rh}-\mathrm{NO} \rightarrow \mathrm{Rh}-\mathrm{N}_{2} \mathrm{O} .
\end{gathered}
$$

\subsection{Effects of $\mathrm{CeO}_{2}$ Addition}

\subsubsection{Catalyst Characterization}

From reactions (4)-(9) described above, it is obvious that redox reactions play a key role in the reduction of $\mathrm{NO}$ by $\mathrm{CO}$, as indicated by the oxidation of $\mathrm{Rh}$ by NO dissociation and the reduction of Rh-O by $\mathrm{CO}$. Cerium oxides are well known to facilitate redox processes by transformation between $\mathrm{Ce}_{2} \mathrm{O}_{3}$ and $\mathrm{CeO}_{2}$ [37-39]. With this in mind, we impregnated ceria onto the best performing binary catalyst, $\mathrm{AuRh}(1: 1) / \mathrm{Al}_{2} \mathrm{O}_{3}$ catalyst. The resulting catalyst was designated henceforth as $\mathrm{AuRh}-\mathrm{CeO}_{x} / \mathrm{Al}_{2} \mathrm{O}_{3}$ and had a AuRh:Ce molar ratio of 1:1.

Properties of the AuRh-CeO ${ }_{x} / \mathrm{Al}_{2} \mathrm{O}_{3}$ catalyst and the corresponding reference catalysts with similar amounts of $\mathrm{Ce}, \mathrm{Au}-\mathrm{CeO} x / \mathrm{Al}_{2} \mathrm{O}_{3}$ and $\mathrm{Rh}-\mathrm{CeO}_{x} / \mathrm{Al}_{2} \mathrm{O}_{3}$, are summarized in Table 2. The surface areas of the three ceria-promoted catalysts slightly decreased compared to those of the corresponding nonpromoted samples (Table 1).

Table 2. BET, STEM, and XPS analyses of $\mathrm{Au}-\mathrm{CeO}_{x} / \mathrm{Al}_{2} \mathrm{O}_{3}, \mathrm{AuRh}-\mathrm{CeO}_{x} / \mathrm{Al}_{2} \mathrm{O}_{3}, \mathrm{Rh}-\mathrm{CeO} \mathrm{O}_{x} / \mathrm{Al}_{2} \mathrm{O}_{3}$, and

\begin{tabular}{|c|c|c|c|c|c|c|}
\hline \multirow[b]{2}{*}{ Catalyst } & \multirow[b]{2}{*}{$\begin{array}{l}\text { BET surface } \\
\text { area }\left(\mathrm{m}^{2} / \mathrm{g}\right)\end{array}$} & \multirow[b]{2}{*}{$\begin{array}{l}\text { Mean Size of AuRh } \\
\text { Particles (nm) }\end{array}$} & \multicolumn{3}{|c|}{ XPS } & \multirow[b]{2}{*}{$\begin{array}{c}\mathrm{Ce}^{3+} \\
\mathrm{Ce}^{3+}+\mathrm{Ce}^{4+}\end{array}$} \\
\hline & & & $\begin{array}{l}\text { Binding energy of } \\
\text { Au4f }_{7 / 2}(\mathrm{eV})\end{array}$ & $\begin{array}{l}\text { Binding energy of } \\
\text { Rh3d }_{5 / 2}(\mathrm{eV})\end{array}$ & $\begin{array}{c}\mathrm{Au} \\
\mathrm{Au}+\mathrm{Rh}\end{array}$ & \\
\hline $\mathrm{Au}-\mathrm{Ce} / \mathrm{Al}_{2} \mathrm{O}_{3}$ & 132 & 5.7 & 83.9 & - & - & 0.34 \\
\hline $\mathrm{AuRh}-\mathrm{Ce} / \mathrm{Al}_{2} \mathrm{O}_{3}$ & 154 & 3.1 & 84.0 & 307.3 & 0.37 & 0.56 \\
\hline $\mathrm{Rh}-\mathrm{Ce} / \mathrm{Al}_{2} \mathrm{O}_{3}$ & 107 & 3.8 & - & 307.5 & - & 0.42 \\
\hline
\end{tabular}

$\mathrm{CeO}_{\mathrm{x}} / \mathrm{Al}_{2} \mathrm{O}_{3}$ catalysts with different molar ratios of AuRh:Ce.

XRD analyses (Figure 8) indicated that the addition of ceria induced the formation of crystalline gold domains in the bimetallic AuRh particles, as evident from the emergence of $\mathrm{Au}(111), \mathrm{Au}(200)$, $\mathrm{Au}(220)$, and $\mathrm{Au}(311)$ reflections. In contrast, the intensity of diffraction patterns due to crystalline $\mathrm{Rh}$ stayed extremely weak and broad, indicating that the Rh nanoparticles were still well-dispersed on the surface. Reflections due to crystalline $\mathrm{CeO}_{2}$ were not discernible for $\mathrm{AuRh}-\mathrm{CeO}_{x} / \mathrm{Al}_{2} \mathrm{O}_{3}$, suggesting the formation of amorphous ceria dispersed on the surface. Figure 9 shows STEM images and particle size distributions of the $\mathrm{AuRh}-\mathrm{CeO}_{x} / \mathrm{Al}_{2} \mathrm{O}_{3}$ catalyst and the reference catalysts. The addition of $\mathrm{CeO} x$ had little influence on the size of the bimetallic AuRh particles (3.1 nm shown in Table 2), whereas it was significant for the $\mathrm{Au}-\mathrm{CeO} x / \mathrm{Al}_{2} \mathrm{O}_{3}$ and $\mathrm{Rh}-\mathrm{CeO}_{x} / \mathrm{Al}_{2} \mathrm{O}_{3}$ catalysts.

Table 2 also summarizes results of XPS analyses of Au 4f, Rh 3d, and Ce 3d. The corresponding raw XPS spectra are provided in Supplementary Materials (Figure S4). A mixture of $\mathrm{Ce}^{3+}$ and $\mathrm{Ce}^{4+}$ oxidation states existed on the surface of the catalysts [70,71]. Hereafter, the cerium oxides are denoted as $\mathrm{CeO}_{x}(x=1.5-2)$. As shown in Table 2, the concentration of $\mathrm{Ce}^{3+}$ in the $\mathrm{AuRh}-\mathrm{CeO}_{x} / \mathrm{Al}_{2} \mathrm{O}_{3}$ catalyst is higher than those of the monometallic reference catalysts and $\mathrm{CeO}_{x} / \mathrm{Al}_{2} \mathrm{O}_{3}$ catalyst, indicating that the presence of bimetallic AuRh promotes the formation of $\mathrm{Ce}^{3+}$ components as $\mathrm{Ce}_{2} \mathrm{O}_{3}$.

$\mathrm{H}_{2}$ TPR profiles (Figure S5 in Supplementary Materials) revealed that the presence of bimetallic $\mathrm{AuRh}$ particles lowered the reduction temperature of $\mathrm{CeO}_{x}$ components from 400 to less than $200{ }^{\circ} \mathrm{C}$. 


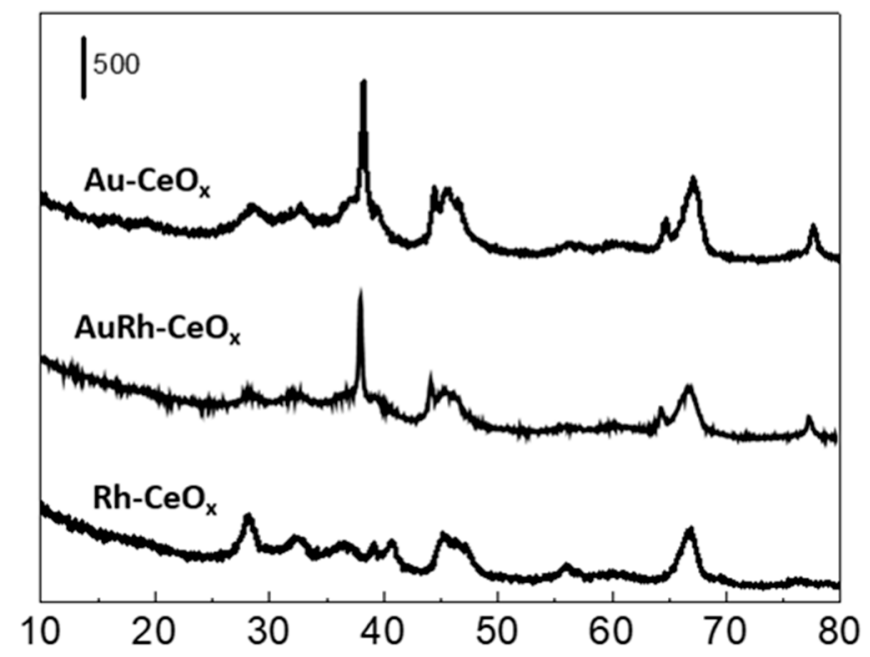

Figure 8. XRD patterns of $\mathrm{Rh}-\mathrm{CeO}_{x} / \mathrm{Al}_{2} \mathrm{O}_{3}, \mathrm{AuRh}-\mathrm{CeO}_{x} / \mathrm{Al}_{2} \mathrm{O}_{3}$, and $\mathrm{CeO}_{x} / \mathrm{Al}_{2} \mathrm{O}_{3}$ catalysts.
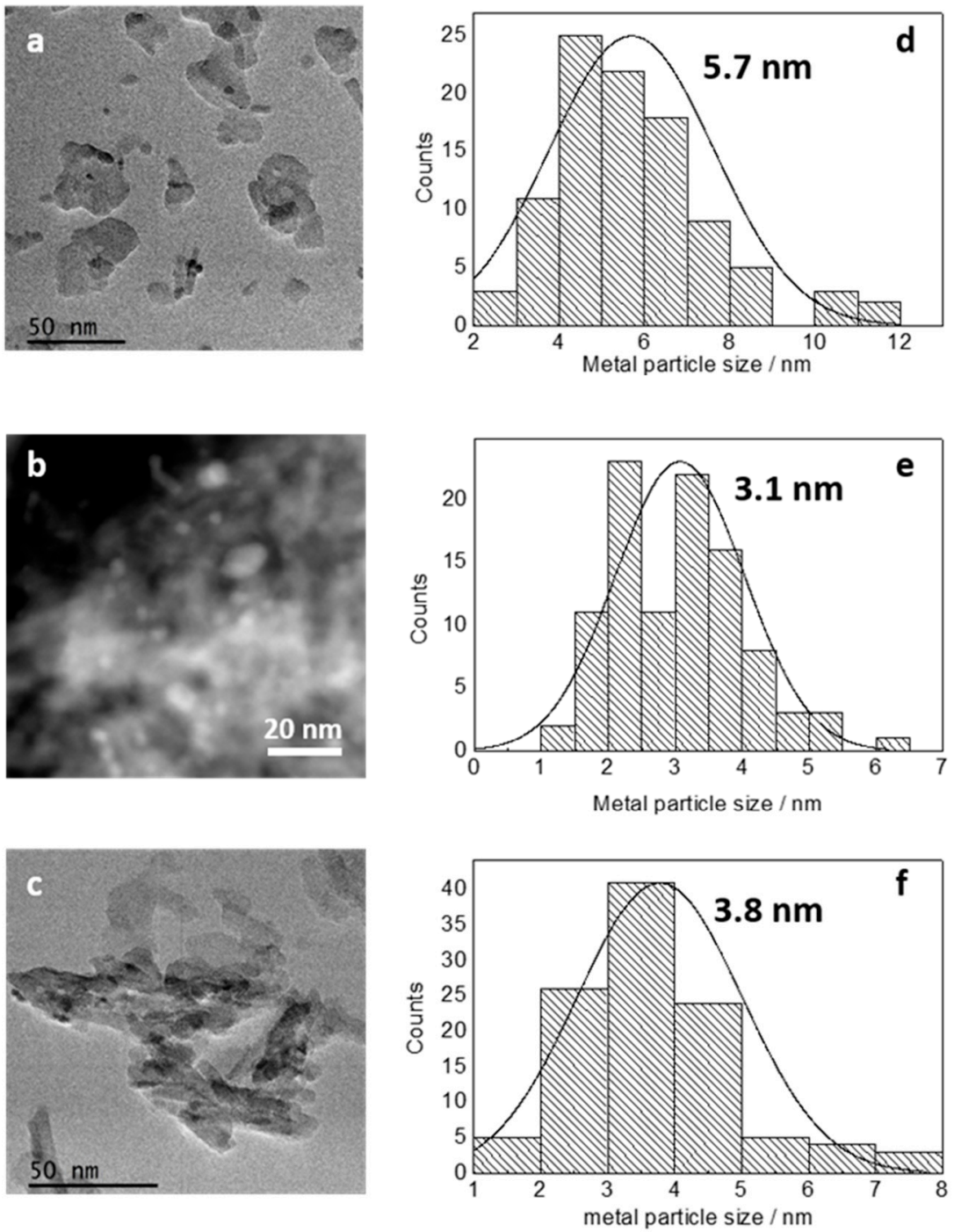

Figure 9. STEM images of different catalysts: (a) $\mathrm{Au}-\mathrm{Ce} / \mathrm{Al}_{2} \mathrm{O}_{3}$, (b) $\mathrm{AuRh}-\mathrm{CeO}_{x} / \mathrm{Al}_{2} \mathrm{O}_{3}$, and (c) $\mathrm{Rh}-\mathrm{Ce} / \mathrm{Al}_{2} \mathrm{O}_{3}$. Particle size distributions of different catalysts: (d) $\mathrm{Au}-\mathrm{Ce} / \mathrm{Al}_{2} \mathrm{O}_{3}$, (e) $\mathrm{AuRh}-\mathrm{CeO}_{x} / \mathrm{Al}_{2} \mathrm{O}_{3}$, and (f) $\mathrm{Rh}-\mathrm{Ce} / \mathrm{Al}_{2} \mathrm{O}_{3}$. The average particle sizes are indicated in the histograms. 


\subsubsection{Catalytic Performance}

Figure 10 shows the $\mathrm{NO}$ conversion and $\mathrm{N}_{2}$ selectivity achieved in the reduction of $\mathrm{NO}$ by $\mathrm{CO}$ for the AuRh-CeO ${ }_{x} / \mathrm{Al}_{2} \mathrm{O}_{3}$ catalyst and the reference catalysts $\mathrm{Au} / \mathrm{CeO} x / \mathrm{Al}_{2} \mathrm{O}_{3}$ and $\mathrm{Rh} / \mathrm{CeO} x / \mathrm{Al}_{2} \mathrm{O}_{3}$. The comparison with the corresponding catalysts without ceria addition (Figure 4) showed that ceria doping enhances the catalytic performance of $\mathrm{AuRh} / \mathrm{Al}_{2} \mathrm{O}_{3}$ and $\mathrm{Rh} / \mathrm{Al}_{2} \mathrm{O}_{3}$ catalysts, whereas that of the $\mathrm{Au} / \mathrm{Al}_{2} \mathrm{O}_{3}$ catalyst declines. Both $\mathrm{NO}$ conversion and $\mathrm{N}_{2}$ selectivity curves of the $\mathrm{AuRh} / \mathrm{Al}_{2} \mathrm{O}_{3}$ and $\mathrm{Rh} / \mathrm{Al}_{2} \mathrm{O}_{3}$ catalysts are shifted towards lower temperature. In contrast, the catalytic performance declined with $\mathrm{CeO}_{x}$ deposition on the $\mathrm{Au} / \mathrm{Al}_{2} \mathrm{O}_{3}$ catalyst. The $\mathrm{N}_{2}$ selectivity of $\mathrm{AuRh} / \mathrm{Al}_{2} \mathrm{O}_{3}$ catalyst was zero at temperatures up to $200{ }^{\circ} \mathrm{C}$ but increased to $69 \%$ for the corresponding ceria-promoted $\mathrm{AuRh}-\mathrm{CeO}_{x} / \mathrm{Al}_{2} \mathrm{O}_{3}$ catalyst, as shown in Table S2 (Supplementary Materials). The only by-product was $\mathrm{N}_{2} \mathrm{O}$. This implied that the addition of $\mathrm{CeO}_{x}$ facilitated the reduction of $\mathrm{N}_{2} \mathrm{O}$ by $\mathrm{CO}$, i.e., reaction (3) described in the Introduction section. Note that the $\mathrm{N}_{2}$ selectivity of the $\left.\mathrm{AuRh}\right) / \mathrm{Al}_{2} \mathrm{O}_{3}$ catalyst showed some fluctuation, depending on the reaction temperature. Since this behavior was perfectly reproducible, we supposed that it is due to a chemical or structural change of the catalysts, possibly leading to a mechanistic change of which clarification needs further investigations. Note that such behavior has earlier been observed in some cases for metal alloys [72] and metal-metal oxide nanocomposites [73,74].
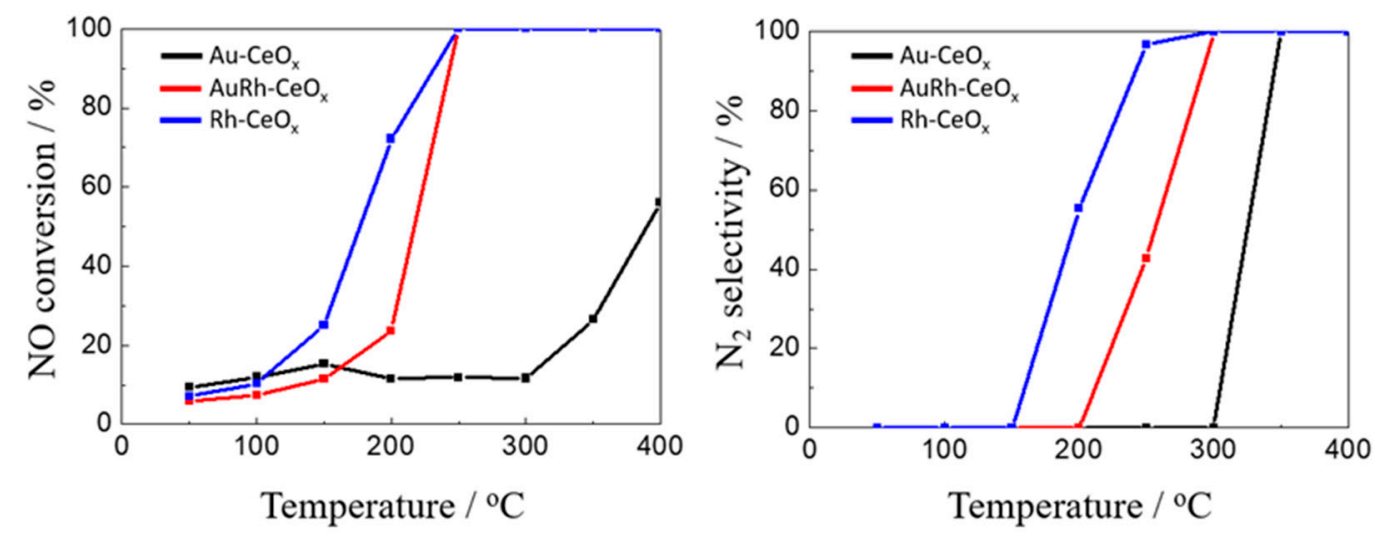

Figure 10. $\mathrm{NO}$ conversion and $\mathrm{N}_{2}$ selectivity of the $\mathrm{Au}-\mathrm{CeO} \mathrm{O}_{x} / \mathrm{Al}_{2} \mathrm{O}_{3} \mathrm{AuRh}-\mathrm{CeO} \mathrm{O}_{x} / \mathrm{Al}_{2} \mathrm{O}_{3}$, and $\mathrm{Rh}-\mathrm{CeO}_{x} / \mathrm{Al}_{2} \mathrm{O}_{3}$ catalysts. Conditions: gas mixture, 2000 ppm NO, 2000 ppm CO, and He balance; total flow rate, $150 \mathrm{~mL} / \mathrm{min}$; GHSV, $18,000 \mathrm{~h}^{-1}$; temperature range, $50-450{ }^{\circ} \mathrm{C}$.

\subsubsection{In Situ DRIFTS Study}

To unveil the role of $\mathrm{CeO}_{x}$ in the reduction of $\mathrm{NO}$ by $\mathrm{CO}$, in situ DRIFTS studies were carried out. Figure 11 shows DRIFT spectra measured during the adsorption of 2000 ppm CO in He balance at $30^{\circ} \mathrm{C}$ for $5 \mathrm{~min}$ (from the red line to the blue line at an interval of $1 \mathrm{~min}$ ). By the addition of $\mathrm{CeO}_{x}$, the intensity of the band of on-top $\mathrm{CO}$ at $2065 \mathrm{~cm}^{-1}$ became dominant while the bands of $\mathrm{Rh}^{+}-(\mathrm{CO})_{2}$ at $2091 \mathrm{~cm}^{-1}$ and $2025 \mathrm{~cm}^{-1}$ were considerably weakened, indicating that there are less $\mathrm{Rh}^{+}$sites in the presence of $\mathrm{CeO}_{x}$. This alludes that $\mathrm{Rh}^{+}$sites are less active for the reaction and the presence of $\mathrm{CeO}_{x}$ enhances the formation of $\mathrm{Rh}^{0}$ sites, which facilitate the reduction of $\mathrm{NO}$ by $\mathrm{CO}$. However, larger amounts of $\mathrm{CeO}_{x}$ addition resulted in a dramatic decrease in the intensity of adsorbed CO due to higher coverage of $\mathrm{CeO}_{x}$ on the bimetallic AuRh particles. 


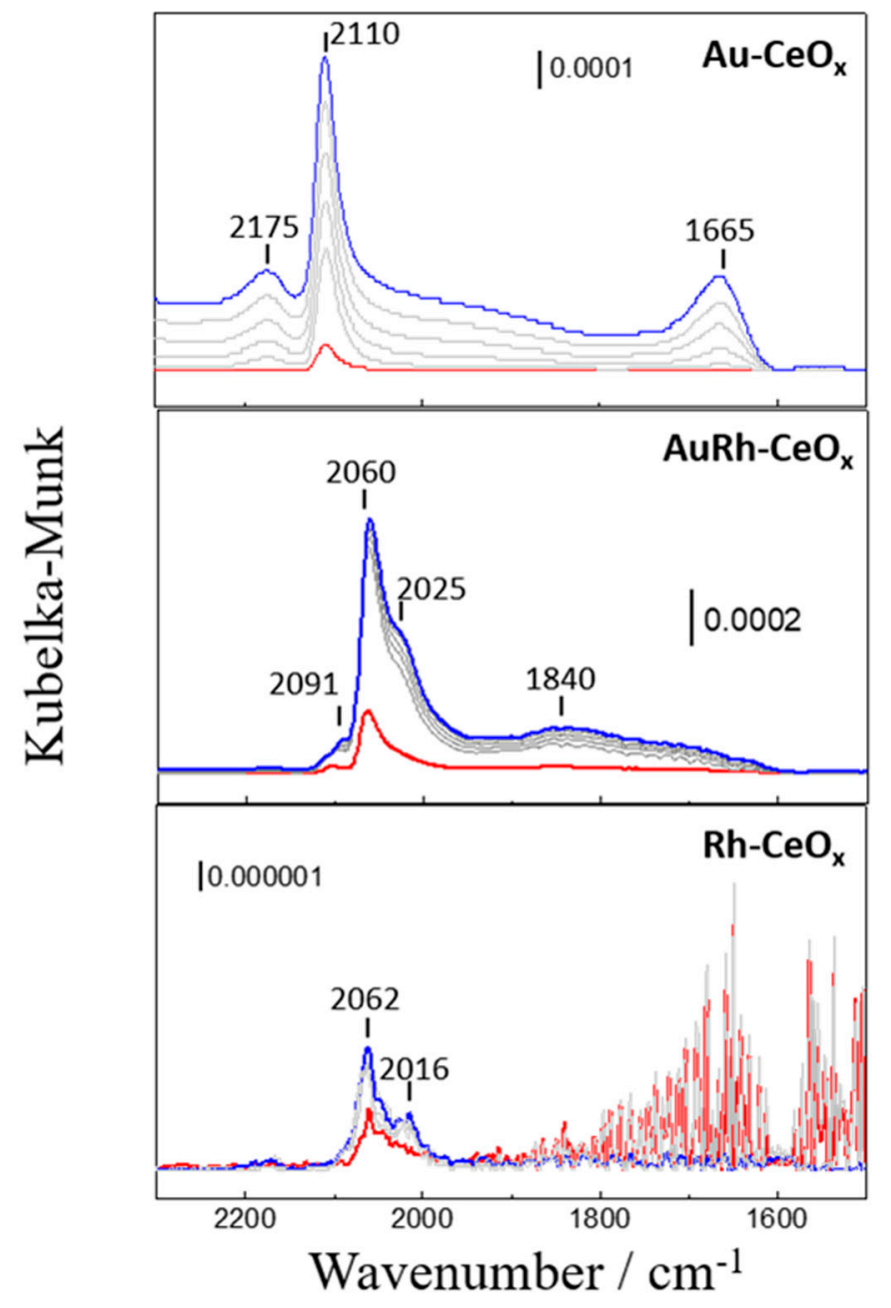

Figure 11. In situ DRIFTS spectra recorded during $\mathrm{CO}$ adsorption on the $\mathrm{Au}-\mathrm{CeO}_{x} / \mathrm{Al}_{2} \mathrm{O}_{3}$, $\mathrm{AuRh}-\mathrm{CeO}_{x} / \mathrm{Al}_{2} \mathrm{O}_{3}$, and $\mathrm{Rh}-\mathrm{CeO}_{x} / \mathrm{Al}_{2} \mathrm{O}_{3}$ at $30{ }^{\circ} \mathrm{C}$ for $5 \mathrm{~min}$ (from the red line to the blue line at an interval of $1 \mathrm{~min}$ ). Gas mixture: $2000 \mathrm{ppm} \mathrm{CO}$ and He balance; total flow rate: $100 \mathrm{~mL} / \mathrm{min}$.

DRIFT spectra of $\mathrm{NO}$ adsorptions are displayed in Figure 12. In line with the $\mathrm{CO}$ adsorption, the band at a higher wavenumber (ca. $1800 \mathrm{~cm}^{-1}$ ) was weakened by the $\mathrm{CeO}_{\mathrm{x}}$ addition. The relative increase in the band at $1683 \mathrm{~cm}^{-1}$ indicated that the $\mathrm{CeO}_{x}$ promoted the transformation of the adsorption configuration from $\mathrm{Rh}-\mathrm{NO}$ to $\mathrm{Rh}-\mathrm{NO}^{\delta-}$. As described in Section 2.1.3, the enriched on-top $\mathrm{NO}^{\delta-}$ is indicative of the formation of metallic $\mathrm{Rh}$ and the strong electron back-donation from $\mathrm{Rh}$ to anti-bonding orbitals of adsorbed NO molecules. The rate constants for NO dissociation determines the activity of the catalysts [68]. Therefore, the dissociation of the negatively charged NO on metallic Rh is a key step for the reduction of NO with CO. A new band at $1890 \mathrm{~cm}^{-1}$ for catalysts promoted with ceria is assigned to adsorbed $\mathrm{NO}$ as $\mathrm{Au}^{\mathrm{n}+}-\mathrm{NO}(n \approx 0)$ complex [68]. DRIFT spectra during co-adsorption of $\mathrm{NO}$ and $\mathrm{CO}$ demonstrated that $\mathrm{CO}$ molecules were adsorbed mainly on cationic Rh while NO molecules occupied metallic Rh (Figure S6 in Supplementary Materials).

In situ DRIFT spectra during the reduction of $\mathrm{NO}$ by $\mathrm{CO}$ at $200{ }^{\circ} \mathrm{C}$ for $10 \mathrm{~min}$ are shown in Figure 13. A broad band at $1835-1842 \mathrm{~cm}^{-1}$ and a band at $1910 \mathrm{~cm}^{-1}$ were assigned to a dinitrosyl complex and positively charged $\mathrm{Rh}-\mathrm{NO}^{+}$species, respectively [3]. The intensity of isocyanate species (-NCO) reached a maximum after $5 \mathrm{~min}$ for the $\mathrm{AuRh}(1: 1) / \mathrm{Al}_{2} \mathrm{O}_{3}$ catalyst, but only took $1 \mathrm{~min}$ for the AuRh-CeO ${ }_{x} / \mathrm{Al}_{2} \mathrm{O}_{3}$ catalyst, showing that $\mathrm{CeO}_{x}$ promoted the formation of isocyanate species. For the AuRh-CeO $x(1: 2) / \mathrm{Al}_{2} \mathrm{O}_{3}$ and $\mathrm{AuRh}-\mathrm{Ce}(1: 5) / \mathrm{Al}_{2} \mathrm{O}_{3}$ catalysts with AuRh:Ce molar ratios of $1: 2$ and 1:5, respectively, a new band at $2173-2196 \mathrm{~cm}^{-1}$ assignable to isocyanate species on $\mathrm{CeO}_{x}$ emerged, 
suggesting the spill-over of isocyanate species from bimetallic AuRh particles to the $\mathrm{CeO}_{x}$ surface. Note that, for the catalysts with a large amount of $\mathrm{CeO}_{x}$, the intensity of isocyanate species decreased greatly after reaching its maximum (highlighted with green and blue lines). This suggested that $\mathrm{CeO}_{x}$ does not only promote the formation of isocyanate species, but also its decomposition to form $\mathrm{N}_{2}$ and $\mathrm{CO}_{2}$. The rapid decomposition of isocyanate species was also confirmed by switching the gas stream from NO and CO to only NO (Figure S7 in Supplementary Materials). For all the catalysts, only bands of $\mathrm{Rh}^{+}-(\mathrm{CO})_{2}$ at $2017-2090 \mathrm{~cm}^{-1}$ were observed under reaction conditions. The $\mathrm{Rh}^{+}-(\mathrm{CO})_{2}$ species seem stable and are most likely not involved in the reaction. This fact further substantiates the vital role of metallic $\mathrm{Rh}$ in the reaction. For the catalysts with high $\mathrm{CeO}_{x}$ loadings, i.e., $\mathrm{AuRh}-\mathrm{CeO}_{x}(1: 2) / \mathrm{Al}_{2} \mathrm{O}_{3}$ and AuRh-CeO ${ }_{x}(1: 5) / \mathrm{Al}_{2} \mathrm{O}_{3}$ catalysts, bands located in the region between 1500 and $1700 \mathrm{~cm}^{-1}$, assigned to nitrate and carbonate species $[3,4]$, grew stronger and more stable. However, the NO conversion and $\mathrm{N}_{2}$ selectivity stayed almost the same for the AuRh-CeO $\mathrm{O}_{x}(1: 2) / \mathrm{Al}_{2} \mathrm{O}_{3}$ and $\mathrm{AuRh}-\mathrm{CeO}_{x}(1: 5) / \mathrm{Al}_{2} \mathrm{O}_{3}$ catalysts (Table S2 in Supplementary Materials). Therefore, these species are considered to be merely spectator species.

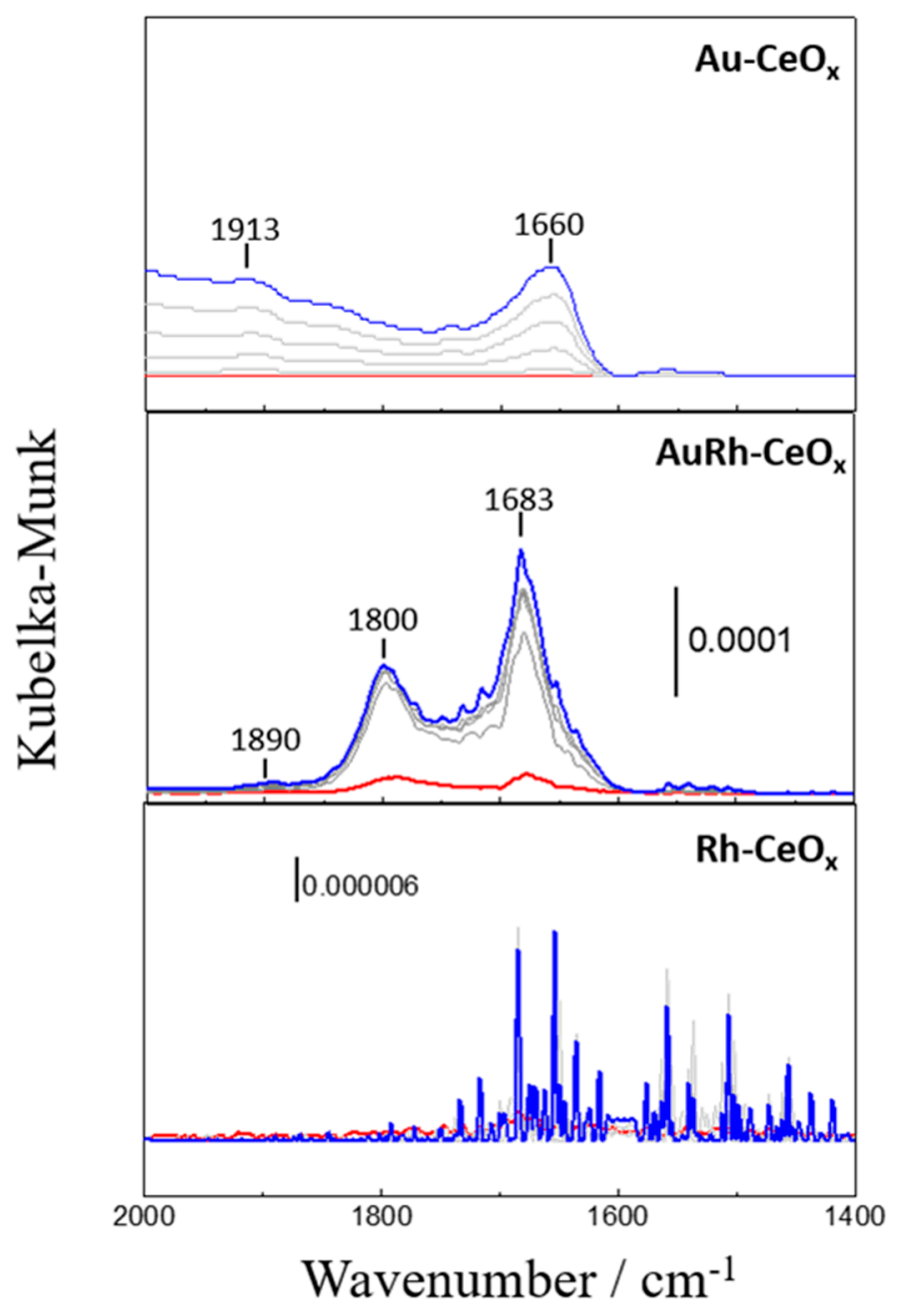

Figure 12. In situ DRIFTS spectra recorded during $\mathrm{NO}$ adsorption on the $\mathrm{Au}-\mathrm{CeO}_{x} / \mathrm{Al}_{2} \mathrm{O}_{3}$, $\mathrm{AuRh}-\mathrm{CeO}_{x} / \mathrm{Al}_{2} \mathrm{O}_{3}$, and $\mathrm{Rh}-\mathrm{CeO}_{x} / \mathrm{Al}_{2} \mathrm{O}_{3}$ catalysts at $30^{\circ} \mathrm{C}$ for $5 \mathrm{~min}$ (from the red line to the blue line at an interval of $1 \mathrm{~min}$ ). Gas mixture: $2000 \mathrm{ppm} \mathrm{NO}$ and He balance; total flow rate: $100 \mathrm{~mL} / \mathrm{min}$. 


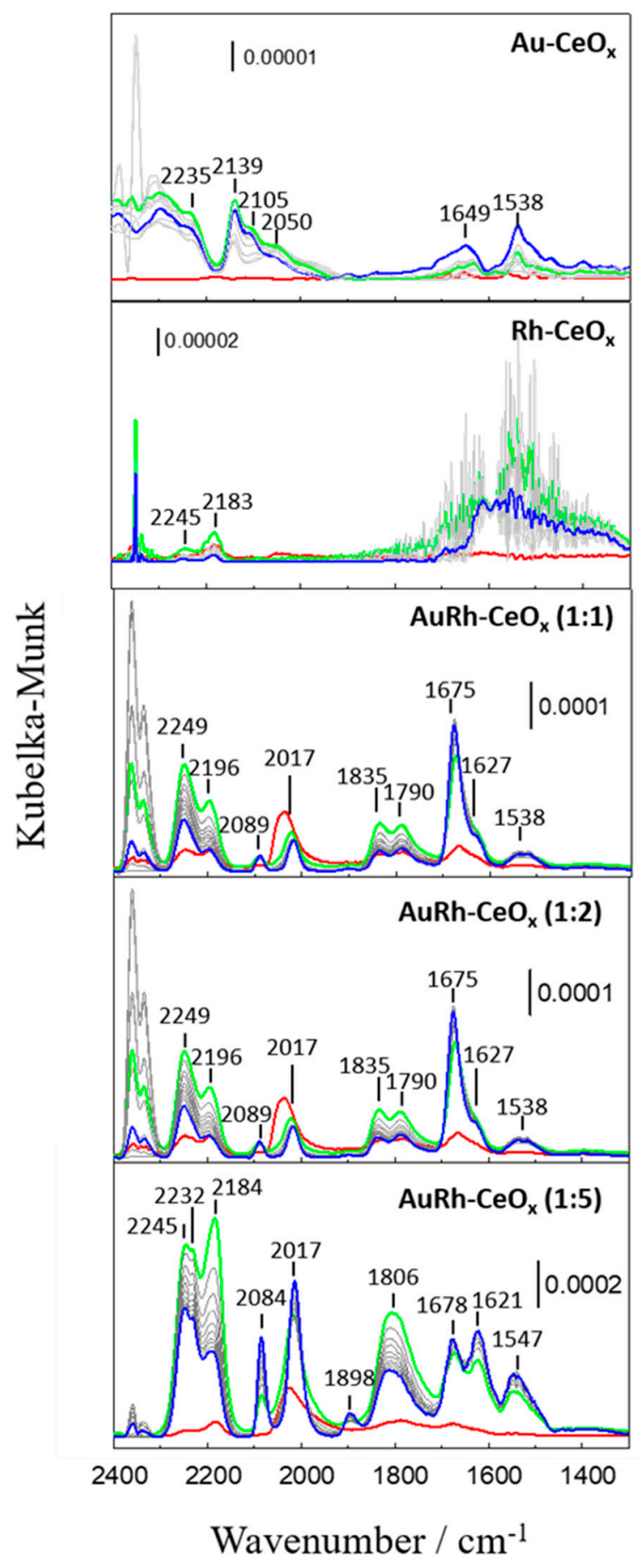

Figure 13. In situ DRIFTS spectra measured during $\mathrm{NO}-\mathrm{CO}$ reaction on the $\mathrm{Au}-\mathrm{CeO}_{x} / \mathrm{Al}_{2} \mathrm{O}_{3}$, $\mathrm{Rh}-\mathrm{CeO}_{x} / \mathrm{Al}_{2} \mathrm{O}_{3}$, and $\mathrm{AuRh}-\mathrm{CeO}_{x} / \mathrm{Al}_{2} \mathrm{O}_{3}$ catalysts with different molar ratios of AuRh:Ce at $200{ }^{\circ} \mathrm{C}$ for $10 \mathrm{~min}$ (from the red line to the blue line at an interval of $1 \mathrm{~min}$ ). Gas mixture: $2000 \mathrm{ppm} \mathrm{NO}, 2000 \mathrm{ppm}$ $\mathrm{CO}$, and He balance; total flow rate: $100 \mathrm{~mL} / \mathrm{min}$.

\section{Materials and Methods}

\subsection{Catalyst Preparation}

A commercially available aluminum oxide (Sigma-Aldrich, nanopowder, particle size: $<50 \mathrm{~nm}$, St. Louis, USA) was used as a catalyst support. Chloroauric acid ( $\mathrm{HAuCl}_{4}$, Energy Chemical, $98 \%$, Shanghai, China), rhodium(III) chloride trihydrate ( $\mathrm{RhCl}_{3} \cdot 3 \mathrm{H}_{2} \mathrm{O}$, Damas-Beta, $98 \%$, Shanghai, China), 
ammonium cerium(IV) nitrate (Sigma-Aldrich, 98\%, St. Louis, USA), PEG-2000 (polyethylene glycol, Energy Chemical), and sodium borohydride $\left(\mathrm{NaBH}_{4}\right.$, Energy Chemical, $98 \%$, Shanghai, China) were all used without further purification.

$\mathrm{Au}, \mathrm{Rh}$, and bimetallic AuRh nanoparticles supported on $\mathrm{Al}_{2} \mathrm{O}_{3}$ were synthesized by aqueous-phase co-reduction of corresponding metal salts with $\mathrm{NaBH}_{4}$ at room temperature [47]. In a typical synthetic method, $3.7 \mathrm{~mL}$ of deionized water, $200 \mathrm{~mL}$ of PEG-2000 $(80 \mathrm{~g} / \mathrm{L})$, and $1 \mathrm{~mL}$ of $50 \mathrm{mM}$ solutions of $\mathrm{HAuCl}_{4}$ and $\mathrm{RhCl}_{3} \cdot 3 \mathrm{H}_{2} \mathrm{O}$ were stirred together in a $50 \mathrm{~mL}$ glass vial for $20 \mathrm{~min}$. The Au:Rh molar ratios of the metal salts were adjusted 1:0, 3:1, 1:1, 1:3, and 0:1, keeping the total metal loading at a nominal value of $3 \mathrm{wt} . \% . \mathrm{Al}_{2} \mathrm{O}_{3}$ powder was then added to the solution under constant stirring. Afterwards, $100 \mathrm{~mL}$ of $20 \mathrm{~g} / \mathrm{L} \mathrm{NaBH}_{4}$ aqueous solution were added slowly to the solution and the suspension was stirred for $1 \mathrm{~h}$. The resulting particles in the suspension were then separated by centrifugation, washed several times with ethanol and dried at $60^{\circ} \mathrm{C}$ overnight.

$\mathrm{AuRh}-\mathrm{CeO} \mathrm{O}_{x} / \mathrm{Al}_{2} \mathrm{O}_{3}$ catalysts with different molar ratios of AuRh:Ce (1:1,2:1, and 1:5) were prepared by post-impregnation with a ceria precursor of the $\mathrm{AuRh}(1: 1) / \mathrm{Al}_{2} \mathrm{O}_{3}$ catalyst. Ammonium cerium(IV) nitrate was dissolved in $100 \mathrm{~mL}$ of deionized water and stirred for $30 \mathrm{~min}$. The $\mathrm{AuRh}(1: 1) / \mathrm{Al}_{2} \mathrm{O}_{3}$ powder was then added to the solution and the suspension was stirred for $1 \mathrm{~h}$. Afterwards, the suspension was transferred to a rotary evaporator and aged for $1 \mathrm{~h}$ at $60^{\circ} \mathrm{C}$, followed by the evaporation of the water at $35^{\circ} \mathrm{C}$ under vacuum and drying at $60^{\circ} \mathrm{C}$ overnight.

As the reference catalysts, $\mathrm{Rh} / \mathrm{Al}_{2} \mathrm{O}_{3}$ and $\mathrm{CeO}_{x} / \mathrm{Al}_{2} \mathrm{O}_{3}$ with a molar amount of $\mathrm{CeO}_{x}$ corresponding to that in $\mathrm{AuRh}-\mathrm{CeO}_{x}(1: 1) / \mathrm{Al}_{2} \mathrm{O}_{3}$ were synthesized in the same manner. These samples were calcined at $500{ }^{\circ} \mathrm{C}$ for $3 \mathrm{~h}$ before reductive pretreatment.

All catalyst samples were pretreated with pure $\mathrm{H}_{2}$ at a flow rate of $100 \mathrm{~mL} / \mathrm{min}$ for $1 \mathrm{~h}$ at $300{ }^{\circ} \mathrm{C}$ (ramping rate: $5^{\circ} \mathrm{C} / \mathrm{min}$ ) prior to characterization by nitrogen adsorption, $\mathrm{X}$-ray diffraction (XRD), X-ray photoelectron spectroscopy (XPS), scanning transmission electron microscopy (STEM), energy-dispersive X-ray spectroscopy (EDX), and diffuse reflectance IR spectroscopy (DRIFTS) as well as catalytic tests.

\subsection{Catalyst Characterization}

Brunauer-Emmett-Teller (BET) surface areas were determined from $\mathrm{N}_{2}$ adsorption isotherms measured at a liquid nitrogen temperature using a Quadrasorb SI instrument (Quantachrome, Boynton Beach, FL, USA). Prior to measurements, the as-prepared samples were degassed at $150^{\circ} \mathrm{C}$ for $1 \mathrm{~h}$ to remove residual water adsorbed on the surface and in the pores. Temperature-programmed reduction (TPR) was carried out with a Quantachrome, ChemBET Pulsar TPR/TPD (temperature-programmed desorption) instrument. One-hundred milligrams of the as-prepared (unreduced) samples were loaded in a U-shaped quartz micro-reactor and then heated at a ramping rate of $10^{\circ} \mathrm{C} / \mathrm{min}$ in $10 \mathrm{vol} \% \mathrm{H}_{2}$ in $\mathrm{Ar}$ at a total flow rate of $15 \mathrm{~mL} / \mathrm{min}$. TPR signals were calibrated by injecting different amounts of $10 \mathrm{vol} \%$ $\mathrm{H}_{2}$ in Ar.

XRD measurements were carried out ex situ using a PANalytical X'Pert diffractometer (Great Malvern, UK) with Pd-filtered $\mathrm{Cu} \mathrm{K} \alpha$ radiation at $60 \mathrm{kV}$ and $55 \mathrm{~mA}$. The surface compositions and oxidation states of the catalysts were analyzed by XPS on a Thermo ESCALAB 250Xi instrument using $\mathrm{Al} \mathrm{K} \alpha$ radiation $(1486.6 \mathrm{eV}, 15 \mathrm{kV}$, and $10.8 \mathrm{~mA})$ to excite photoelectrons at a $50 \mathrm{eV}$ pass energy at an energy scale calibrated versus $\mathrm{Ag} 3 \mathrm{~d}_{5 / 2}$ at $1 \mathrm{eV}$. The instrument was equipped with an in situ pretreatment chamber connected to the XPS chamber. The sample holder was transferred between the two chambers by a manipulator. The pretreatment conditions were the same as those described in Section 3.3. STEM (JEOL, JEM-2100, $200 \mathrm{kV}$, Tokyo, Japan) was used to examine the size distribution of the mono- and bimetallic nanoparticles deposited on the alumina support and EDX was employed to gain some information about the elemental distributions of $\mathrm{Au}$ and $\mathrm{Rh}$ in the nanoparticles. The samples previously pretreated with pure hydrogen for $1 \mathrm{~h}$ at $300^{\circ} \mathrm{C}$ were used for both STEM and EDX measurements. Particle size distributions were based on analyzing more than 100 particles per sample. 
In situ IR spectroscopic studies were carried out using a Fourier-transform infrared spectrometer (Bruker Optics, Vertex 70, Billerica, MA, USA) equipped with a liquid $\mathrm{N}_{2}$-cooled mercury cadmium telluride (MCT) detector at a spectral resolution of $4 \mathrm{~cm}^{-1}$ and a scanning velocity of $60 \mathrm{kHz}$. A ceramic cup with $20 \mathrm{mg}$ of the samples was placed in an in situ DRIFTS reactor with three ZnSe windows, connected to an automated 4-way Valco valve (VICI AG International) and mass flow controllers (Azbil Control Solution Co., Ltd., Tokyo, Japan). The DRIFTS compartment and all the IR beam lines were purged with dry air supplied by a compressor/dryer-combined system (EKOM) to remove the $\mathrm{H}_{2} \mathrm{O}$ vapor, of which IR bands overlapped with the IR fingerprint regions. Prior to in situ DRIFTS measurements, the catalysts were exposed to pure $\mathrm{H}_{2}$ at a flow rate of $100 \mathrm{~mL} / \mathrm{min}$ for $1 \mathrm{~h}$ at $300{ }^{\circ} \mathrm{C}$ (ramping rate: $5{ }^{\circ} \mathrm{C} / \mathrm{min}$ ) in the DRIFTS reactor. For all the experiments, $2000 \mathrm{ppm} \mathrm{NO}$ and/or 2000 ppm CO in He balance (He purity: 99.9999\%) were utilized at a total flow rate of $100 \mathrm{~mL} / \mathrm{min}$. Before all IR measurements, background spectra were taken under helium flow.

\subsection{Catalytic Reaction}

The catalytic performance was examined employing a fixed-bed micro-flow reactor system. Three-hundred milligrams of catalysts were packed into the stainless-steel tube reactor with an inner diameter of $8 \mathrm{mM}$. Prior to catalytic tests, the catalysts were pretreated with pure $\mathrm{H}_{2}$ (flow rate: $100 \mathrm{~mL} / \mathrm{min}$ ) at $300^{\circ} \mathrm{C}$ for $1 \mathrm{~h}$ at a ramping rate of $5^{\circ} \mathrm{C} / \mathrm{min}$. Residual $\mathrm{H}_{2}$ in the gas lines and adsorbed hydrogen on the catalyst surface were removed by keeping the catalyst in a He stream at $300{ }^{\circ} \mathrm{C}$ for $10 \mathrm{~min}$. Afterwards, the reactor was cooled to $50^{\circ} \mathrm{C}$ and a gas mixture $(2000 \mathrm{ppm} \mathrm{CO}$ and $2000 \mathrm{ppm}$ $\mathrm{NO}$ in He balance) was added at a total flow rate of $150 \mathrm{~mL} / \mathrm{min}$, affording a gas hourly space velocity (GHSV) of $18,000 \mathrm{~h}^{-1}$ (length of catalyst bed: $1 \mathrm{~cm}$, catalyst bed volume: $0.5 \mathrm{~cm}^{3}$ ). The gaseous compositions were analyzed using a gas chromatograph (Fili, 9750 GC, Shanghai, China) equipped with a TCD detector and a molecular sieve $5 \mathrm{~A}$ column and a NO-NO $\mathrm{NO}_{2}-\mathrm{NO}_{x}$ analyzer (Thermo Scientific, 42i-HL, Waltham, MA, USA). Catalytic performance data were recorded after the gaseous compositions at the reactor outlet reaching a steady-state (30-70 $\mathrm{min})$ at each measurement temperature. The same experiments were repeated three times to ensure the reproducibility of the data (less than $\pm 1.0 \%$ ). Blind tests using the empty tube reactor showed no significant activity.

\section{Conclusions}

Bimetallic AuRh nanoparticles with different Au:Rh ratios (3:1, 1:1, and 1:3) and mean sizes (3-7 nm) were prepared by aqueous-hase co-reduction of corresponding noble metal salts with $\mathrm{NaBH}_{4}$ and deposited on alumina as a support. The nanoparticles were made up of well-distributed noble metal atoms forming an alloy with $\mathrm{Rh}$ enriched in the surface region. The AuRh/alumina catalysts were examined, concerning their potential for the reduction of $\mathrm{NO}$ by $\mathrm{CO}$. The activity for NO reduction decreased with the increasing Au:Rh ratio, most likely due to unfavorable formation of cationic $\mathrm{Rh}$ clusters $\mathrm{Rh}^{+}-(\mathrm{CO})_{2}$ in the presence of the reactant $\mathrm{CO}$, as uncovered by in situ DRIFTS. To explore the feasibility of enhancing the performance of the bimetallic $\mathrm{AuRh} / \mathrm{Al}_{2} \mathrm{O}_{3}$ catalysts, cerium oxide was added to the $\mathrm{AuRh}(1: 1) / \mathrm{Al}_{2} \mathrm{O}_{3}$ catalyst by post-impregnation. DRIFTS, XPS, and XRD analyses showed that $\mathrm{Ce}$ was present as $\mathrm{Ce}^{3+}$ and $\mathrm{Ce}^{4+}$ in the form of well-dispersed $\mathrm{CeO}_{\mathrm{x}}$. The catalytic performances of the AuRh-CeO ${ }_{x} / \mathrm{Al}_{2} \mathrm{O}_{3}$ catalyst as well as that of the $\mathrm{Rh} / \mathrm{Al}_{2} \mathrm{O}_{3}$ catalyst were strongly enhanced compared to that of the parent $\mathrm{AuRh}(1: 1) / \mathrm{Al}_{2} \mathrm{O}_{3}$ catalyst, contrasting the behavior of the $\mathrm{Au}-\mathrm{CeO}_{\mathrm{x}} / \mathrm{Al}_{2} \mathrm{O}_{3}$ catalyst where ceria doping had no beneficial effect on the catalytic performance. The reason for the activity enhancement is ascribed to the redox properties of $\mathrm{CeO}_{x}$ facilitating the creation of metallic Rh sites, which are considered to be crucial for the reduction of NO by CO. Furthermore, in situ DRIFTS investigations during the reduction of $\mathrm{NO}$ by $\mathrm{CO}$ at $200{ }^{\circ} \mathrm{C}$ proved that the presence of $\mathrm{CeO}_{x}$ enhances the formation of intermediate isocyanate species and their reaction with $\mathrm{NO}$ to produce $\mathrm{N}_{2}$ and $\mathrm{CO}_{2}$. Finally, it should be stressed that it might be possible to further enhance the catalytic performance the AuRh-CeO $/ \mathrm{Al}_{2} \mathrm{O}_{3}$ catalyst for the reduction of $\mathrm{NO}$ by $\mathrm{CO}$ by optimizing their composition. Overall, the study shows that alumina-supported bimetallic AuRh 
catalysts hardly provide a better catalytic performance in the reduction of $\mathrm{NO}$ by $\mathrm{CO}$, compared to the well-known monometallic Rh/alumina catalyst. Doping with ceria enhances the catalytic performance of both catalysts.

Supplementary Materials: The supplementary materials are available online at http://www.mdpi.com/2073-4344/ 9/11/937/s1: Figure S1: XPS spectra of Au/alumina, Rh/alumina, and Au-Rh/alumina catalysts. Table S1: Catalytic performance in $\mathrm{NO}$ reduction by CO at $200{ }^{\circ} \mathrm{C}$. Figure S2: In situ DRIFTS spectra measured during $\mathrm{NO}$ and $\mathrm{CO}$ co-adsorption on the Au/alumina, Rh/alumina, and $\mathrm{Au}-\mathrm{Rh} /$ alumina catalysts. Figure S3: In situ DRIFTS spectra during NO introduction following the NO-CO reaction. Figure S4: XPS spectra of the Au-Rh(1:1)/alumina, $\mathrm{CeO}_{x}$ /alumina, and $\mathrm{AuRh}-\mathrm{CeO}_{x}$ /alumina catalysts. Figure S5: $\mathrm{H}_{2} \mathrm{TPR}$ profiles of $\mathrm{CeO}_{x} /$ alumina and $\mathrm{AuRh}-\mathrm{CeO}_{x}$ /alumina catalysts. Table S2: Catalytic performance of ceria-promoted $\mathrm{Au}-\mathrm{Rh}(1: 1) /$ alumina catalysts. Figure S6: In situ DRIFTS spectra measured during NO and CO co-adsorption on the Au- $\mathrm{Rh}(1: 1) /$ alumina and AuRh- $\mathrm{CeO}_{x}$ /alumina catalysts. Figure S7: In situ DRIFTS spectra during NO introduction following the NO-CO reaction on the $\mathrm{Au}-\mathrm{Rh}(1: 1) /$ alumina, $\mathrm{CeO}_{x} /$ alumina and $\mathrm{AuRh}-\mathrm{CeO}_{x} /$ alumina catalysts.

Author Contributions: Conceptualization, N.M. and A.B.; investigation, X.W. and H.W.; writing of original draft preparation, X.W.; writing of review and editing, X.W., N.M., and A.B.; supervision, N.M. and A.B.; project administration, N.M.; funding acquisition, N.M.

Funding: This research was funded by the National Science Foundation of China (NSFC), grant number 21377017.

Acknowledgments: Yan Xie at the Gold Catalysis Research Center (GCRC) at the Dalian Institute of Chemical Physics (DICP) is acknowledged for measuring XRD, XPS, and STEM. Jinsuo Gao at the Dalian University of Technology is acknowledged for BET measurements.

Conflicts of Interest: The authors declare no conflict of interest.

\section{References}

1. Taylor, K.A.; Paskewitz, S.M.; Copeland, R.S.; Koros, J.; Beach, R.F.; Githure, J.I.; Collins, F.H. Comparison of two ribosomal DNA-based methods for differentiating members of the Anopheles gambiae complex (Diptera: Culicidae). J. Med. Entomol. 1993, 30, 457-461. [CrossRef] [PubMed]

2. Shelef, M.; Graham, G.W. Why Rhodium in Automotive Three-Way Catalysts? Catal. Rev. 1994, 36, $433-457$. [CrossRef]

3. Chafik, T.; Kondarides, D.I.; Verykios, X.E. Catalytic Reduction of NO by CO over Rhodium Catalysts. J. Catal. 2000, 190, 446-459. [CrossRef]

4. Kondarides, D.I.; Chafik, T.; Verykios, X.E. Catalytic Reduction of NO by CO over Rhodium Catalysts. J. Catal. 2000, 193, 303-307. [CrossRef]

5. Kondarides, D.I.; Chafik, T.; Verykios, X.E. Catalytic Reduction of NO by CO over Rhodium Catalysts: 2. Effect of Oxygen on the Nature, Population, and Reactivity of Surface Species Formed under Reaction Conditions. J. Catal. 2000, 191, 147-164. [CrossRef]

6. Honkala, K.; Pirilä, P.; Laasonen, K. CO and NO adsorption and co-adsorption on the $\operatorname{Pd}\left(\begin{array}{lll}1 & 1 & 1\end{array}\right)$ surface. Surf. Sci. 2001, 489, 72-82. [CrossRef]

7. Khristova, M.S.; Petrović, S.P.; Terlecki-Baričević, A.; Mehandjiev, D.R. Catalytic reduction of NO by CO over Pd-Doped Perovskite-type catalysts. Cent. Eur. J. Chem. 2009, 7, 857. [CrossRef]

8. Rasko, J.; Szabo, Z.; Bansagi, T.; Solymosi, F. FTIR study of the photo-induced reaction of $\mathrm{NO}+\mathrm{CO}$ on $\mathrm{Rh} / \mathrm{TiO}_{2}$. Phys. Chem. Chem. Phys. 2001,3,4437-4443. [CrossRef]

9. Ivanova, E.; Mihaylov, M.; Thibault-Starzyk, F.; Daturi, M.; Hadjiivanov, K. FTIR spectroscopy study of CO and $\mathrm{NO}$ adsorption and co-adsorption on $\mathrm{Pt} / \mathrm{TiO}_{2}$. J. Mol. Catal. A Chem. 2007, 274, 179-184. [CrossRef]

10. Haruta, M.; Kobayashi, T.; Sano, H.; Yamada, N. Novel gold catalysts for the oxidation of carbon monoxide at a temperature far below $0{ }^{\circ} \mathrm{C}$. Chem. Lett. 1987, 16, 405-408. [CrossRef]

11. Ayati, A.; Ahmadpour, A.; Bamoharram, F.F.; Tanhaei, B.; Mänttäri, M.; Sillanpää, M. A review on catalytic applications of $\mathrm{Au} / \mathrm{TiO}_{2}$ nanoparticles in the removal of water pollutant. Chemosphere 2014, 107, 163-174. [CrossRef] [PubMed]

12. Corti, C.W.; Holliday, R.J.; Thompson, D.T. Commercial aspects of gold catalysis. Appl. Catal. A-Gen. 2005, 291, 253-261. [CrossRef]

13. Sugunan, A.; Thanachayanont, C.; Dutta, J.; Hilborn, J.G. Heavy-metal ion sensors using chitosan-capped gold nanoparticles. Sci. Technol. Adv. Mater. 2005, 6, 335. [CrossRef] 
14. Daniel, M.-C.; Astruc, D. Gold Nanoparticles: Assembly, Supramolecular Chemistry, Quantum-Size-Related Properties, and Applications toward Biology, Catalysis, and Nanotechnology. Chem. Rev. 2004, 104, $293-346$. [CrossRef] [PubMed]

15. Ishida, T.; Haruta, M. Gold catalysts: Towards sustainable chemistry. Angew. Chem. Int. Ed. 2007, 46, 7154-7156. [CrossRef] [PubMed]

16. Haruta, M. Novel catalysis of gold deposited on metal oxides. Catal. Surv. Asia 1997, 1, 61-73. [CrossRef]

17. Hashmi, A.S.K.; Hutchings, G.J. Gold catalysis. Angew. Chem.-Int. Ed. 2006, 45, 7896-7936. [CrossRef] [PubMed]

18. Mallat, T.; Baiker, A. Potential of Gold Nanoparticles for Oxidation in Fine Chemical Synthesis. Annu. Rev. Chem. Biomol. Eng. 2012, 3, 11-28. [CrossRef] [PubMed]

19. Min, B.K.; Friend, C.M. Heterogeneous gold-based catalysis for green chemistry: Low-temperature CO oxidation and propene oxidation. Chem. Rev. 2007, 107, 2709-2724. [CrossRef] [PubMed]

20. Stratakis, M.; Garcia, H. Catalysis by Supported Gold Nanoparticles: Beyond Aerobic Oxidative Processes. Chem. Rev. 2012, 112, 4469-4506. [CrossRef] [PubMed]

21. Ilieva, L.; Pantaleo, G.; Velinov, N.; Tabakova, T.; Petrova, P.; Ivanov, I.; Avdeev, G.; Paneva, D.; Venezia, A.M. $\mathrm{NO}$ reduction by $\mathrm{CO}$ over gold catalysts supported on Fe-loaded ceria. Appl. Catal. B-Environ. 2015, 174, 176-184. [CrossRef]

22. Bond, G.C.; Thompson, D.T. Catalysis by Gold. Catal. Rev. 1999, 41, 319-388. [CrossRef]

23. Debeila, M.A.; Coville, N.J.; Scurrell, M.S.; Hearne, G.R. DRIFTS studies of the interaction of nitric oxide and carbon monoxide on $\mathrm{Au}-\mathrm{TiO}_{2}$. Catal. Today 2002, 72, 79-87. [CrossRef]

24. Ueda, A.; Haruta, M. Nitric oxide reduction with hydrogen, carbon monoxide, and hydrocarbons over gold catalysts. Gold Bull. 1999, 32, 3-11. [CrossRef]

25. Gao, F.; Wang, Y.; Goodman, D.W. CO/NO and $\mathrm{CO} / \mathrm{NO} / \mathrm{O}_{2}$ reactions over a $\mathrm{Au}-\mathrm{Pd}$ single crystal catalyst. J. Catal. 2009, 268, 115-121. [CrossRef]

26. Granger, P.; Dujardin, C.; Paul, J.F.; Leclercq, G. An overview of kinetic and spectroscopic investigations on three-way catalysts: Mechanistic aspects of the $\mathrm{CO}+\mathrm{NO}$ and $\mathrm{CO}+\mathrm{N}_{2} \mathrm{O}$ reactions. J. Mol. Catal. A Chem. 2005, 228, 241-253. [CrossRef]

27. Da Cunha, M.C.P.M.; Weber, M.; Nart, F.C. On the adsorption and reduction of $\mathrm{NO}_{3}{ }^{-}$ions at $\mathrm{Au}$ and $\mathrm{Pt}$ electrodes studied by in situ FTIR spectroscopy. J. Electroanal. Chem. 1996, 414, 163-170. [CrossRef]

28. Venkov, T.; Fajerwerg, K.; Delannoy, L.; Klimev, H.; Hadjiivanov, K.; Louis, C. Effect of the activation temperature on the state of gold supported on titania: An FT-IR spectroscopic study. Appl. Catal. A-Gen. 2006, 301, 106-114. [CrossRef]

29. Klimev, H.; Fajerwerg, K.; Chakarova, K.; Delannoy, L.; Louis, C.; Hadjiivanov, K. Oxidation of gold metal particles supported on $\mathrm{TiO}_{2}$ : An FTIR study by means of low-temperature CO adsorption. J. Mater. Sci. 2007, 42, 3299-3306. [CrossRef]

30. Solymosi, F.; Bánsági, T.; Suli Zakar, T. Surface interaction and reaction of $\mathrm{NO}+\mathrm{CO}$ on a supported Au catalyst. Phys. Chem. Chem. Phys. 2003, 5, 4724-4730. [CrossRef]

31. Solymosi, F.; Bánsági, T.; Zakar, T.S. Infrared Study of the $\mathrm{NO}+\mathrm{CO}$ Interaction over $\mathrm{Au} / \mathrm{TiO}_{2}$ Catalyst. Catal. Lett. 2003, 87, 7-10. [CrossRef]

32. Fernández-García, M.; Gómez Rebollo, E.; Guerrero Ruiz, A.; Conesa, J.C.; Soria, J. Influence of ceria on the dispersion and reduction/oxidation behaviour of alumina-supported copper catalysts. J. Catal. 1997, 172, 146-159. [CrossRef]

33. Martínez-Arias, A.; Fernández-García, M.; Hungría, A.B.; Iglesias-Juez, A.; Duncan, K.; Smith, R.; Anderson, J.A.; Conesa, J.C.; Soria, J. Effect of thermal sintering on light-off performance of $\mathrm{Pd} /(\mathrm{Ce}, \mathrm{Zr}) \mathrm{O}_{x} / \mathrm{Al}_{2} \mathrm{O}_{3}$ three-way catalysts: Model gas and engine tests. J. Catal. 2001, 204, 238-248. [CrossRef]

34. Ge, C.; Liu, L.; Liu, Z.; Yao, X.; Cao, Y.; Tang, C.; Gao, F.; Dong, L. Improving the dispersion of $\mathrm{CeO}_{2}$ on $\gamma-\mathrm{Al}_{2} \mathrm{O}_{3}$ to enhance the catalytic performances of $\mathrm{CuO} / \mathrm{CeO}_{2} / \gamma-\mathrm{Al}_{2} \mathrm{O}_{3}$ catalysts for $\mathrm{NO}$ removal by CO. Catal. Commun. 2014, 51, 95-99. [CrossRef]

35. Trovarelli, A. Catalytic Properties of Ceria and $\mathrm{CeO}_{2}-$ Containing Materials. Catal. Rev. 1996, 38, 439-520. [CrossRef]

36. Cunningham, J.; O’Brien, S.; Sanz, J.; Rojo, J.M.; Soria, J.A.; Fierro, J.L.G. Exceptional susceptibility of ceria-supported rhodium catalyst to inhibitory SMSI effects including acetone hydrogenation. J. Mol. Catal. 1990, 57, 379-396. [CrossRef] 
37. Liu, N.; Chen, X.; Zhang, J.; Schwank, J.W. DRIFTS study of photo-assisted catalytic CO + NO redox reaction over $\mathrm{CuO} / \mathrm{CeO}_{2}-\mathrm{TiO}_{2}$. Catal. Today 2015, 258 Pt 1, 139-147. [CrossRef]

38. Chen, J.; Zhan, Y.; Zhu, J.; Chen, C.; Lin, X.; Zheng, Q. The synergetic mechanism between copper species and ceria in $\mathrm{NO}$ abatement over $\mathrm{Cu} / \mathrm{CeO}_{2}$ catalysts. Appl. Catal. A-Gen. 2010, 377, 121-127. [CrossRef]

39. Martínez-Arias, A.; Soria, J.; Conesa, J.C.; Seoane, X.L.; Arcoya, A.; Cataluña, R. NO reaction at surface oxygen vacancies generated in cerium oxide. J. Chem. Soc. Faraday Trans. 1995, 91, 1679-1687. [CrossRef]

40. Louis, C. Chemical Preparation of Supported Bimetallic Catalysts. Gold-Based Bimetallic, a Case Study. Catalysts 2016, 6, 110. [CrossRef]

41. Gao, F.; Goodman, D.W. Pd-Au bimetallic catalysts: Understanding alloy effects from planar models and (supported) nanoparticles. Chem. Soc. Rev. 2012, 41, 8009-8020. [CrossRef] [PubMed]

42. Duan, T.; Zhang, R.G.; Ling, L.X.; Wang, B.J. Insights into the Effect of Pt Atomic Ensemble on $\mathrm{HCOOH}$ Oxidation over Pt-Decorated Au Bimetallic Catalyst To Maximize Pt Utilization. J. Phys. Chem. C 2016, 120, 2234-2246. [CrossRef]

43. Xu, C.L.; Du, Y.Q.; Li, C.; Yang, J.; Yang, G. Insight into effect of acid/base nature of supports on selectivity of glycerol oxidation over supported Au-Pt bimetallic catalysts. Appl. Catal. B-Environ. 2015, 164, 334-343. [CrossRef]

44. Sterchele, S.; Biasi, P.; Centomo, P.; Campestrini, S.; Shchukarev, A.; Rautio, A.R.; Mikkola, J.P.; Salmi, T.; Zecca, M. The effect of the metal precursor-reduction with hydrogen on a library of bimetallic Pd-Au and $\mathrm{Pd}-\mathrm{Pt}$ catalysts for the direct synthesis of $\mathrm{H}_{2} \mathrm{O}_{2}$. Catal. Today 2015, 248, 40-47. [CrossRef]

45. Liu, L.C.; Zi, X.H.; Dai, H.X.; Zhao, Z.; Wang, X.P.; He, H. Preparation and Characterization of $\mathrm{Rh}-\mathrm{Au} /$ gamma- $\mathrm{Al}_{2} \mathrm{O}_{3}$ Three-Way Nanocatalysts. Chin. J. Catal. 2010, 31, 781-787.

46. Garcia, S.; Zhang, L.; Piburn, G.W.; Henkelman, G.; Humphrey, S.M. Microwave Synthesis of Classically Immiscible Rhodium-Silver and Rhodium-Gold Alloy Nanoparticles: Highly Active Hydrogenation Catalysts. ACS Nano 2014, 8, 11512-11521. [CrossRef] [PubMed]

47. Essinger-Hileman, E.R.; DeCicco, D.; Bondi, J.F.; Schaak, R.E. Aqueous room-temperature synthesis of $\mathrm{Au}-\mathrm{Rh}, \mathrm{Au}-\mathrm{Pt}, \mathrm{Pt}-\mathrm{Rh}$, and Pd-Rh alloy nanoparticles: Fully tunable compositions within the miscibility gaps. J. Mater. Chem. 2011, 21, 11599-11604. [CrossRef]

48. Thanh-Son, N.; Laurenti, D.; Afanasiev, P.; Konuspayeva, Z.; Piccolo, L. Titania-Supported gold-based nanoparticles efficiently catalyze the hydrodeoxygenation of guaiacol. J. Catal. 2016, 344, 136-140.

49. Konuspayeva, Z.; Afanasiev, P.; Nguyen, T.-S.; Di Felice, L.; Morfin, F.; Nhat-Tai, N.; Nelayah, J.; Ricolleau, C.; Li, Z.Y.; Yuan, J.; et al. Au-Rh and Au-Pd nanocatalysts supported on rutile titania nanorods: Structure and chemical stability. Phys. Chem. Chem. Phys. 2015, 17, 28112-28120. [CrossRef] [PubMed]

50. Okamoto, H.; Massalski, T.B. The Au-Rh (Gold-Rhodium) System. Bull. Alloy. Phase Diagr. 1984, 5, 384-387. [CrossRef]

51. Piccolo, L.; Li, Z.Y.; Demiroglu, I.; Moyon, F.; Konuspayeva, Z.; Berhault, G.; Afanasiev, P.; Lefebvre, W.; Yuan, J.; Johnston, R.L. Understanding and controlling the structure and segregation behaviour of AuRh nanocatalysts. Sci. Rep. 2016, 6, 35226. [CrossRef] [PubMed]

52. Monev, M.; Pfund, A.; Beck, G.; Petrov, K.; Bretzler, R.; Heuberger, U.; Zielonka, A. Effect of current density on composition and structure of electrodeposited Au-Ni alloy coatings. Trans. IMF 2013, 91, 176-181. [CrossRef]

53. Wang, Z.-J.; Zhao, Y.; Cui, L.; Du, H.; Yao, P.; Liu, C.-J. $\mathrm{CO}_{2}$ reforming of methane over argon plasma reduced $\mathrm{Rh} / \mathrm{Al}_{2} \mathrm{O}_{3}$ catalyst: A case study of alternative catalyst reduction via non-hydrogen plasmas. Green Chem. 2007, 9, 554-559. [CrossRef]

54. Zhang, H.; Deng, X.; Jiao, C.; Lu, L.; Zhang, S. Preparation and catalytic activities for $\mathrm{H}_{2} \mathrm{O}_{2}$ decomposition of Rh/Au bimetallic nanoparticles. Mater. Res. Bull. 2016, 79, 29-35. [CrossRef]

55. Marx, S.; Krumeich, F.; Baiker, A. Surface Properties of Supported, Colloid-Derived Gold/Palladium Monoand Bimetallic Nanoparticles. J. Phys. Chem. C 2011, 115, 8195-8205. [CrossRef]

56. Dick, K.; Dhanasekaran, T.; Zhang, Z.Y.; Meisel, D. Size-Dependent melting of silica-encapsulated gold nanoparticles. J. Am. Chem. Soc. 2002, 124, 2312-2317. [CrossRef] [PubMed]

57. Yasuda, H.; Mori, H. Cluster-Size dependence of alloying behavior in gold clusters. Z. Phys. D At. Mol. Clust. 1994, 31, 131-134. [CrossRef]

58. Kohiki, S.; Oki, K.; Konishi, F. Extra-Atomic Relaxation Effect on the Binding Energy of Reference Gold in X-ray Photoelectron Spectroscopy. Anal. Sci. 1985, 1, 115-117. [CrossRef] 
59. Raskó, J.; Koós, Á.; Baán, K.; Kiss, J. Characterization of Au-Rh/TiO 2 catalysts by CO adsorption; XPS, FTIR and TPD experiments. React. Kinet. Catal. Lett. 2007, 90, 187-195. [CrossRef]

60. Chen, L.; Choong, C.K.S.; Zhong, Z.; Huang, L.; Ang, T.P.; Hong, L.; Lin, J. Carbon monoxide-free hydrogen production via low-temperature steam reforming of ethanol over iron-promoted Rh catalyst. J. Catal. 2010, 276, 197-200. [CrossRef]

61. Araya, P.; Weissmann, C. FTIR study of the oxidation reaction of $\mathrm{CO}$ with $\mathrm{O}_{2}$ over bimetallic $\mathrm{Pd}-\mathrm{Rh} / \mathrm{SiO} \mathrm{O}_{2}$ catalysts in an oxidized state. Catal. Lett. 2000, 68, 33-39. [CrossRef]

62. Evans, J.; Dent, A.J.; Diaz-Moreno, S.; Fiddy, S.G.; Jyoti, B.; Newton, M.A.; Tromp, M. In Situ Structure-Function Studies of Oxide Supported Rhodium Catalysts by Combined Energy Dispersive XAFS and DRIFTS Spectroscopies; X-Ray Absorption Fine Structure-Xafs13; Hedman, B., Painetta, P., Eds.; AIP: Melville, NY, USA, 2007; p. 603.

63. Iordan, A.; Zaki, M.I.; Kappenstein, C.; Geron, C. XPS and in situ IR spectroscopic studies of CO/Rh/Al $\mathrm{O}_{3}$ and $\mathrm{CO} / \mathrm{Rh} / \mathrm{K}-\mathrm{Al}_{2} \mathrm{O}_{3}$ at high temperatures: Probing the impact of the potassium functionalization of the support. Phys. Chem. Chem. Phys. 2003, 5, 1708-1715. [CrossRef]

64. Gómez-Cortés, A.; Díaz, G.; Zanella, R.; Ramírez, H.; Santiago, P.; Saniger, J.M. Au-Ir/TiO 2 prepared by deposition precipitation with urea: Improved activity and stability in CO oxidation. J. Phys. Chem. C 2009, 113, 9710-9720. [CrossRef]

65. Hasegawa, Y.; Haneda, M.; Kintaichi, Y.; Hamada, H. Zn-promoted $\mathrm{Rh} / \mathrm{SiO}_{2}$ catalyst for the selective reduction of $\mathrm{NO}$ with $\mathrm{H}_{2}$ in the presence of $\mathrm{O}_{2}$ and $\mathrm{SO}_{2}$. Appl. Catal. B-Environ. 2005, 60, 41-47. [CrossRef]

66. Debeila, M.A.; Coville, N.J.; Scurrell, M.S.; Hearne, G.R. Direct observation of thermally activated NO adsorbate species on $\mathrm{Au}-\mathrm{TiO}_{2}$ : DRIFTS studies. J. Mol. Catal. A Chem. 2004, 219, 131-141. [CrossRef]

67. Sobczak, I.; Musialska, K.; Pawlowski, H.; Ziolek, M. $\mathrm{NO}$ and $\mathrm{C}_{3} \mathrm{H}_{6}$ adsorption and coadsorption in oxygen excess-A comparative study of different type zeolites modified with gold. Catal. Today 2011, 176, 393-398. [CrossRef]

68. Araya, P.; Gracia, F.; Cortés, J.; Wolf, E.E. FTIR study of the reduction reaction of $\mathrm{NO}$ by $\mathrm{CO}$ over $\mathrm{Rh} / \mathrm{SiO}_{2}$ catalysts with different crystallite size. Appl. Catal. B-Environ. 2002, 38, 77-90. [CrossRef]

69. Na-Ranong, D.; Yuangsawad, R.; Kitchaiya, P.; Aida, T. Application of periodic operation to kinetic study of $\mathrm{NO}-\mathrm{CO}$ reaction over $\mathrm{Rh} / \mathrm{Al}_{2} \mathrm{O}_{3}$. Chem. Eng. J. 2009, 146, 275-286. [CrossRef]

70. Zhu, W.; Xiao, S.; Zhang, D.; Liu, P.; Zhou, H.; Dai, W.; Liu, F.; Li, H. Highly Efficient and Stable Au/CeO $-\mathrm{CiO}_{2}$ Photocatalyst for Nitric Oxide Abatement: Potential Application in Flue Gas Treatment. Langmuir 2015, 31, 10822-10830. [CrossRef] [PubMed]

71. Bêche, E.; Charvin, P.; Perarnau, D.; Abanades, S.; Flamant, G. Ce 3d XPS investigation of cerium oxides and mixed cerium oxide $\left(\mathrm{Ce}_{\mathrm{x}} \mathrm{Ti}_{\mathrm{y}} \mathrm{O}_{\mathrm{z}}\right)$. Surf. Interface Anal. 2008, 40, 264-267. [CrossRef]

72. Hirano, T.; Ozawa, Y.; Sekido, T.; Ogino, T.; Miyao, T.; Naito, S. The role of additives in the catalytic reduction of $\mathrm{NO}$ by $\mathrm{CO}$ over $\mathrm{Pd}-\mathrm{In} / \mathrm{SiO}_{2}$ and $\mathrm{Pd}-\mathrm{Pb} / \mathrm{SiO}_{2}$ catalysts. Appl. Catal. A-Gen. 2007, 320, 91-97. [CrossRef]

73. Hirano, T.; Ozawa, Y.; Sekido, T.; Ogino, T.; Miyao, T.; Naito, S. Marked effect of In, Pb and Ce addition upon the reduction of $\mathrm{NO}$ by $\mathrm{CO}$ over $\mathrm{SiO}_{2}$ supported Pd catalysts. Catal. Commun. 2007, 8, 1249-1254. [CrossRef]

74. Wang, X.; Maeda, N.; Baiker, A. Synergistic Effects of Au and $\mathrm{FeO}_{\mathrm{x}}$ Nanocomposites in Catalytic NO Reduction with CO. ACS Catal. 2016, 6, 7898-7906. [CrossRef]

(C) 2019 by the authors. Licensee MDPI, Basel, Switzerland. This article is an open access article distributed under the terms and conditions of the Creative Commons Attribution (CC BY) license (http://creativecommons.org/licenses/by/4.0/). 